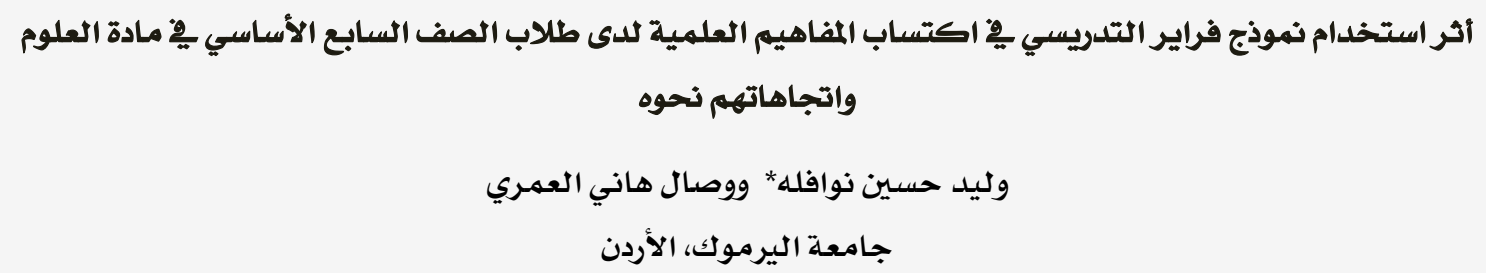

\title{
The Effect of Using Fryer Teaching Model on 7th Grade Students' Acquisition of Scientific Concepts and their Attitudes toward it
}

Waleed H. Nawafleh* \& Wesal H. Alomari Yarmouk University, Jordan

Abstract: This study aimed to investigate the effect of using Fryer teaching model on 7th grade students' acquisition of scientific concepts. The researchers were interested in testing if differences between students' acquisitions of scientific concepts were dependent on previous achievement. Also important was to test if students' acquisition of scientific concepts correlated with attitudes towards using Fryer model. To achieve the objectives of the study, a quasi-experimental method was used. Two instruments were developed: a test to measure the acquisition of the scientific concepts and a questionnaire to measure students' attitudes. The study sample consisted of 72 students who were divided into two groups: one $(n=37)$ studied science using Fryer model; the other $(n=35)$ used the traditional method. At the end of the experiment, concepts acquisition test was administered to both groups; while the attitude scale was administered to the experimental group. The results revealed that there were statistically significant differences $(p<0.05)$ in the acquisition of scientific concepts in favor of the experimental group; and the previous achievement in favor of high achievers. There was an interaction effect between method and previous achievement. The results also revealed a statistically significant correlation between the acquisition of scientific concepts and attitudes towards learning using Fryer model among 7 graders.

Keywords: Fryer Model, scientific concepts, $7^{\text {th }}$ grad students, attitudes.

*wnawafleh2@yahoo.om 


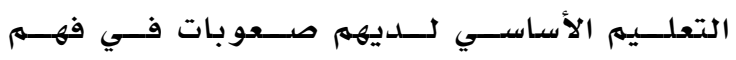
الهفاهيه، و أنهم يحفظون المفاهيم العلميــة دون

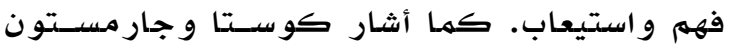
Garmston, 2001)(Costa \&

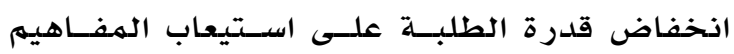

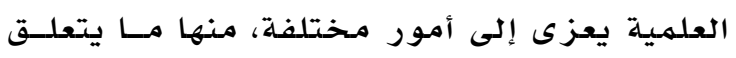

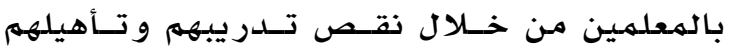
على الأساليب التدريسية الفاعلة أو عدم رغبـيستهم

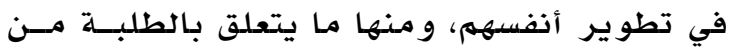

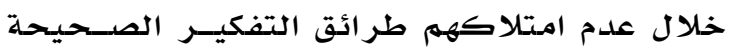

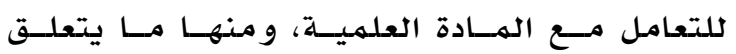
بالمنهج المقرر، أو السياسـة التربوية الهية المتبعـة. و يقتضي الأمـر البحث عن طر ائق واسـتر اتيجيات جديدة في تحقيق الأهداف التدريسية، وذلكي لأن النان

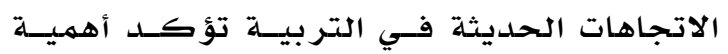

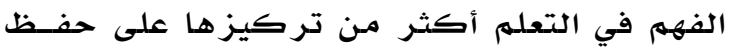

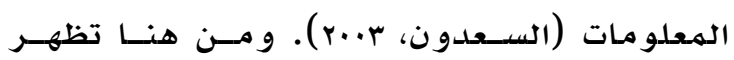
الحاجة إلى و جود طرائق و نماذج تدريسيـة يمكن

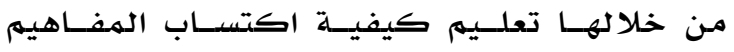
العلمية، ويمكـن مـن خلالهـا تحقيـق مشــار كة

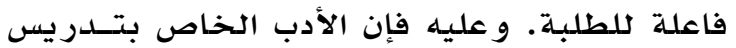
العلوم يعرض استر اتيجيات وطر ائق تدريس عدة من شأنها تحقيق أهم أهداف تدريس العلوم وهو

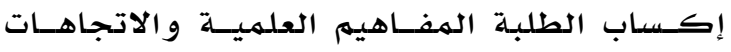
نحو العلوم. كذلك تؤكد الجهات المختصدة في

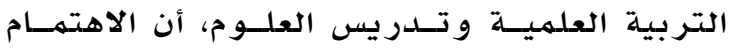

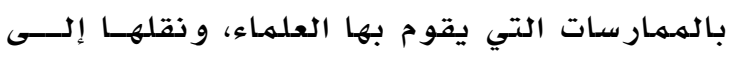
الصف المددرسي لتدريب الطلبـة الهتعلمين عليها،

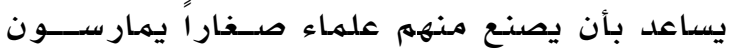
العلهم كمـا يمسارسـه العلمــاء الكبـار National) .Research Council (NRC), 2000)

و تدريس أشكال المعرفة العلميلة ومنها المفـاهيم

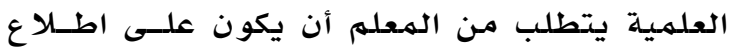

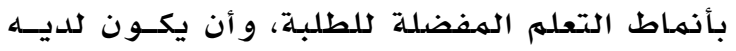
القدرة على التحكم بالأساليب التي يتبعها، وينوع

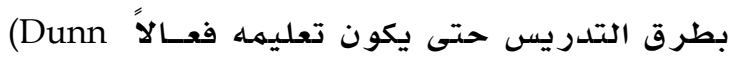
\& Price, 1987)

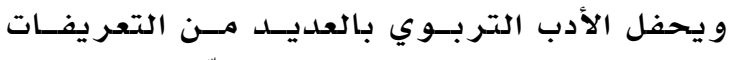

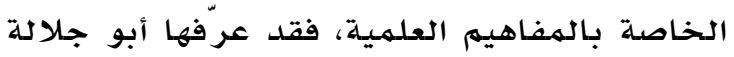

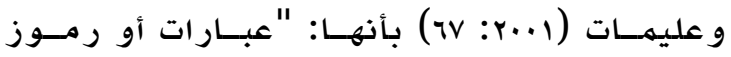

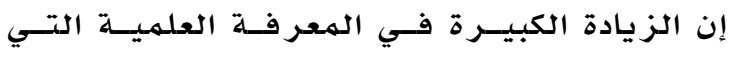

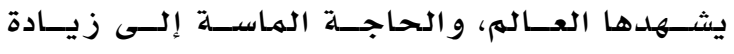

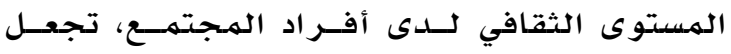

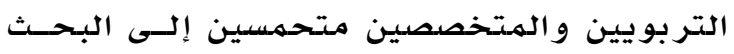
عن أنسب الطر ائق التي يمكن من خلالها تودئ ولهيل

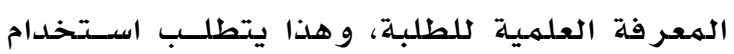
طر ائق فعالة تسهل على الطلبـة اكتساب المعرفة فهرة العلمية بصورة أفضل.

و في مجال تدريس العلوم، تُشكل المعر فة العلمية

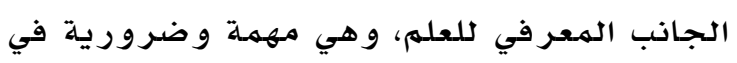

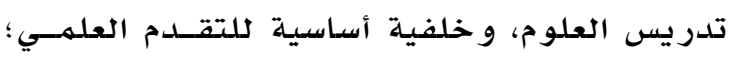

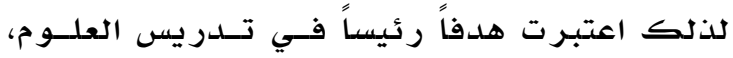

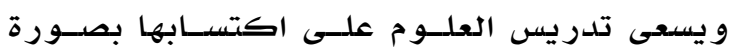
وظيفية. ويؤكد الأدب التربوي أن هذه المعرفة تعمسل علــى تعسديل ســلو ك المــتعلهم و تفكيــره ووجدانه، لذا ينبغي أن تكون مـرتبطــة بمشـكلات

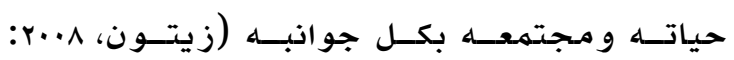
الصفحة ).

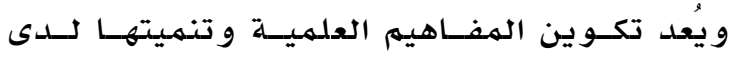

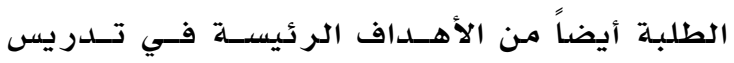

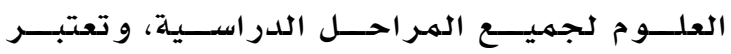
المفاهيهم ركيزة أساسية تسهم فـي انتقـال أثـر

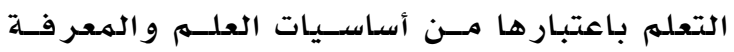
العلمية. و بنـاء" علـى ذلــك، فـإن بنــاء المفــاهيم

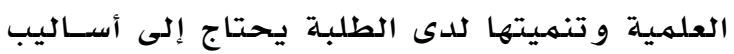

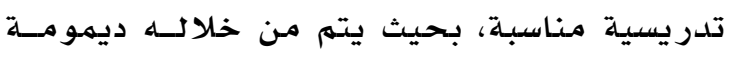

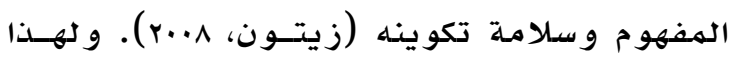

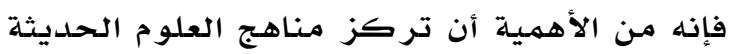

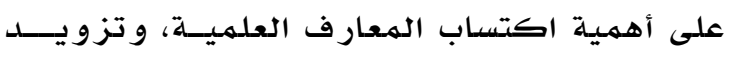

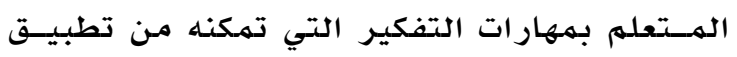

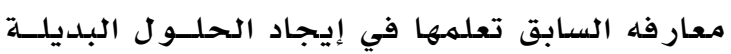

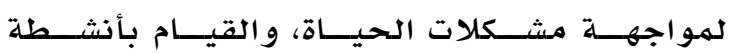

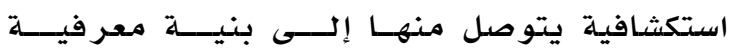

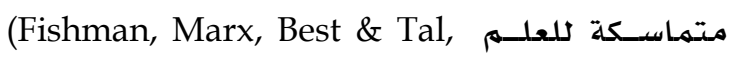
.2003)

و أشارت نتائج العديد مـن الدراسـات التي تناودـ الكشف عن درجة اكتساب المفاهيم العلمية مثل:

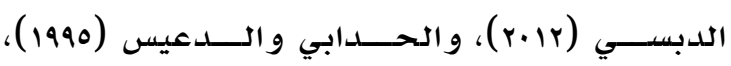

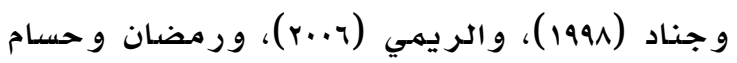

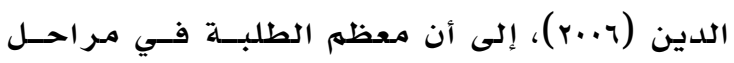




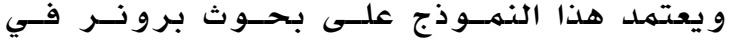

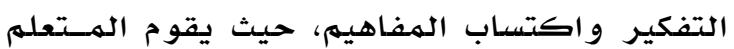

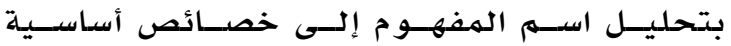
و أخرى غير أسـاسية، ويدللون علـى فهمهــم مــن

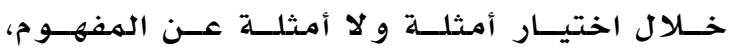

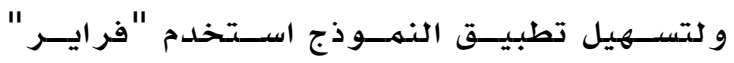
مخططاً رسو مياً على شكل مستطيل، يتكـون مــن أربعة مـربعات يتوسطها اسهم الهفهوم فـي دائــرة كها في شكل ا (الجزار، r...r).

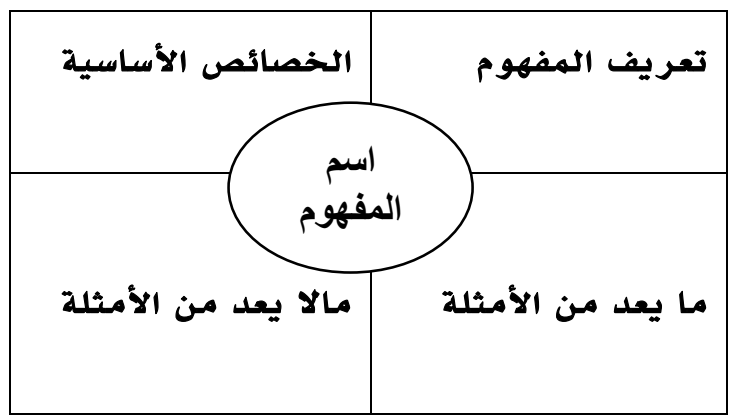

شكل ا : الثكل العام لمخطط رسومي لنموذج "فراير" لاكتساب المفهوم و تتلخص إجراءات تطبيق نموذج فراير بأن يقوم

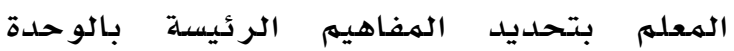
و علاقتها بالمفاهيم الأخرى المرتبطة بها، بحيث

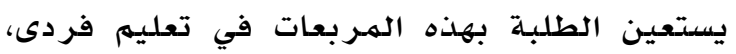
أو في مجمو عات صغيرة، أو فى مناقشة جماعية،

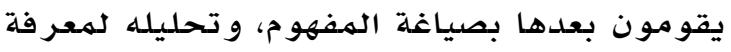

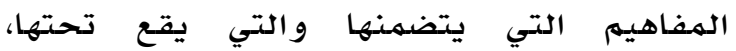
و توضيح مدى الاتفاق أو الاختالاف بين الهفاهيم

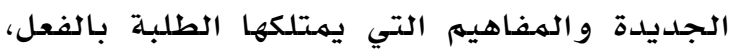

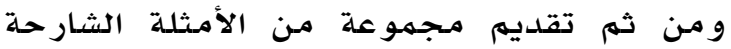
و المفسرة للهفهوم الجديد، و كذلك تقديم

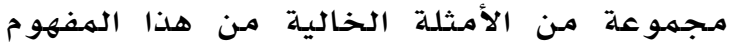
لتحديد الهفهوم الذي يدرسه الطلبة، و أخيرا يقوم بتقديم مجمو عة من الأمثلة و اللاأمثلة

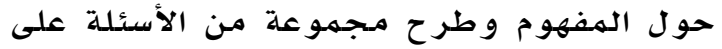

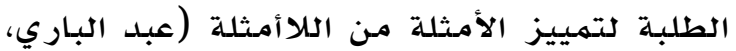
. $(r \cdot 1)$

و أهم مــا يتميـز بـه هـذا النهــوذج، أنــه مــنظم

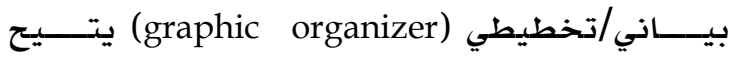
للمتعلم رؤية عدد كبير من أجـززاء الهعلومهـات حول المفهوم في نظرة واحدة سريعة، ووبالتـالي

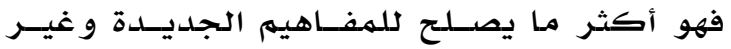

لفظية تدل على معلومات و أفكار مجرردة لأشـياء

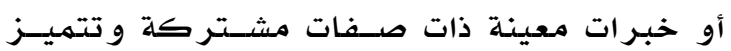

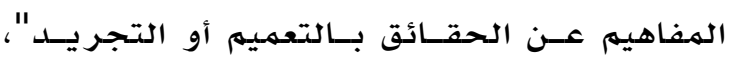

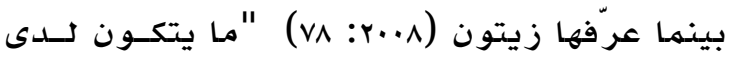
الفرد من معنى و فهم يرتبط بكلمهة أو عبـارة أو

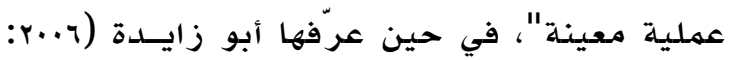

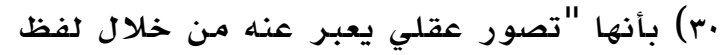

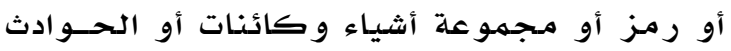
التي تشتر ك في صفة معينة أو أكثر مـع تجاهل

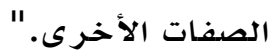

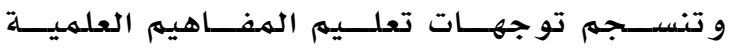

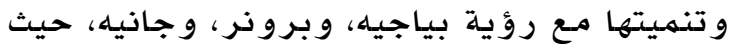

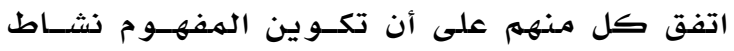

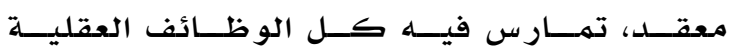

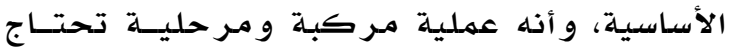

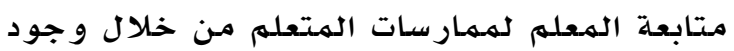
مواقـف مخحصصــة لهـــا الغــرض، و أن تكـــوين

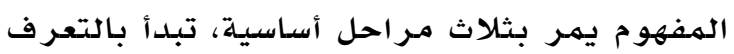

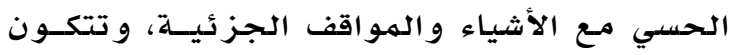
بشكل عفوي عند الطفل قبل دخوله المدررسة، ثم

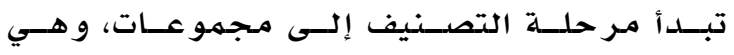

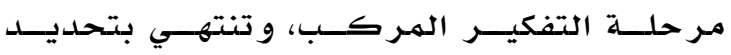

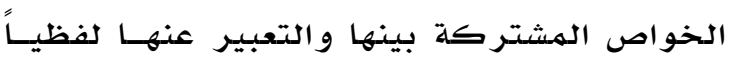

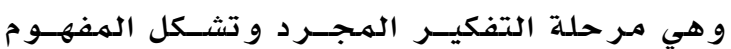

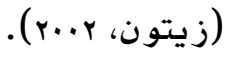

و يعود الاهتهام بعملية اكتساب الهفهوم إلى

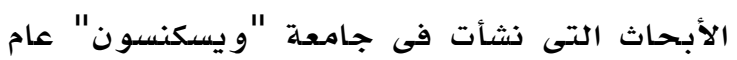

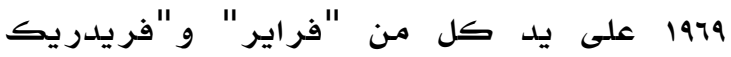

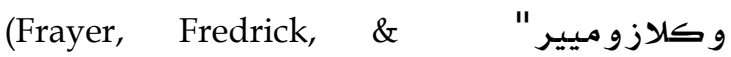

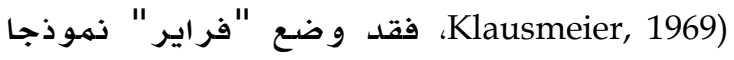
عرف "بنمود ج فراير " Frayer Model) لاكتسـاب

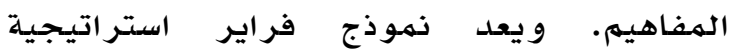
تدريسية تساعد المعلم عندما يهدف إلى تعليه طلبته مفاهيهم جديدة. وعادة يقوم الهعلم

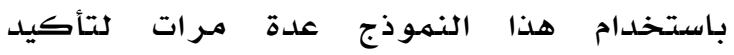

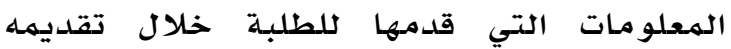
مفاهيم مهمة و أساسية خلال الفصل الذي يلدرسه للطلبـة (Macceca, 2007). 
التجريبي ذي التصميم قبلي-بعـدي للمـجموعـات

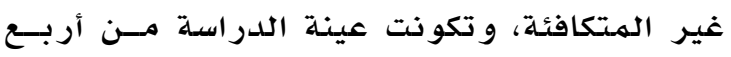

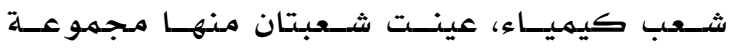

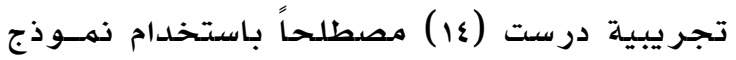

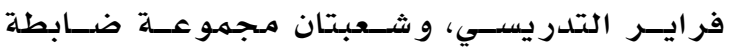

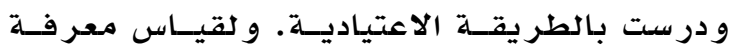
المفردات تم بناء اختبار يغطي المصطلحات التي

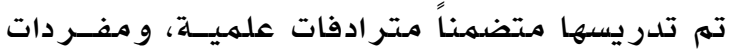

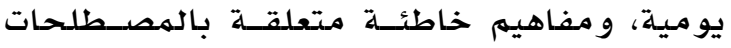

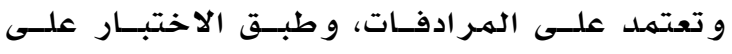

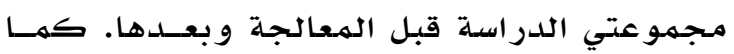

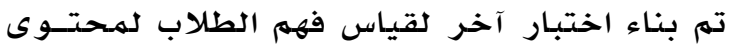

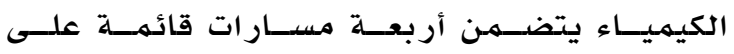

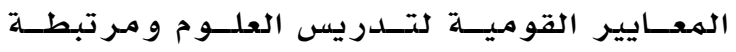

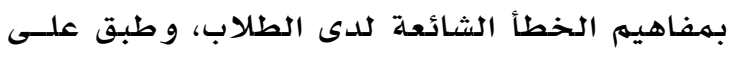

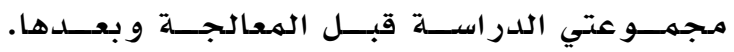

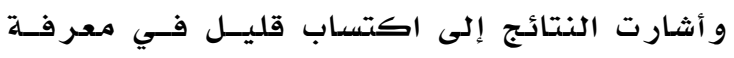

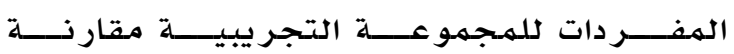
بالمجسموعة الضـابطة، لكنــه غيـر دال إحصــائياً.

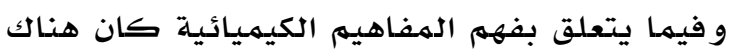

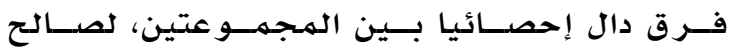
المجمبو عة الضابطة.

وفـي بحسث إجر ائــي تطبيقـي أجسـر اه تر اســـ

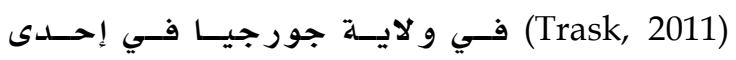

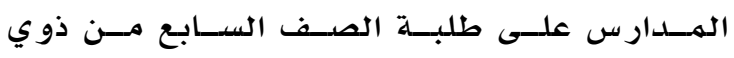

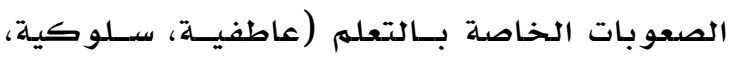

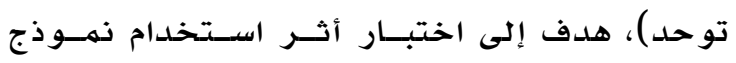

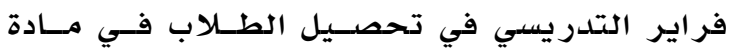

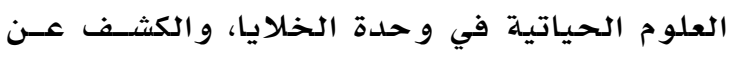

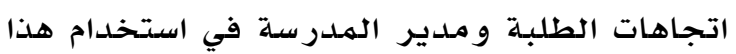

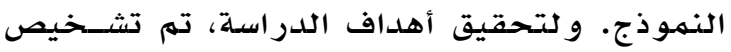

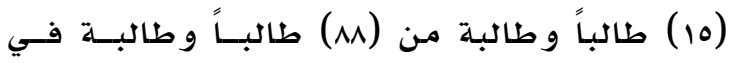

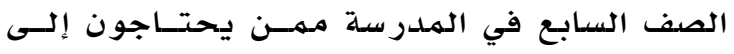
تعليه خاص، وطبق علـيهـ اختبـار قبلـي خـاص

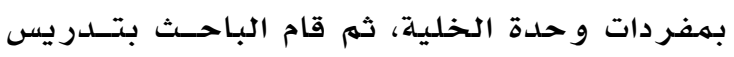
الوحدة باستخدام نهـوذذج فر ايـر، و بعـدها طبـق

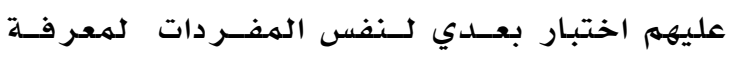

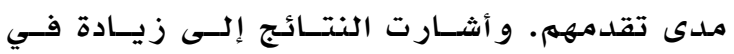

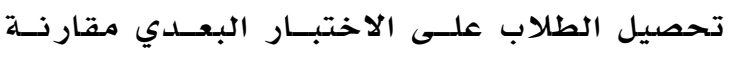

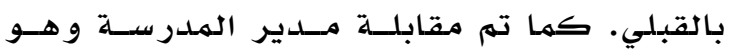

المألو فة للطلبـة، كما يتهـيز هــذا النهــوذج بأنسه يسـاعد الطـلاب علــى التفكيـر بطــرق متعـــدةد،

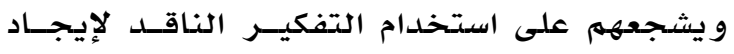
(Teacher resource guide, العلاجات بين المفاهيه

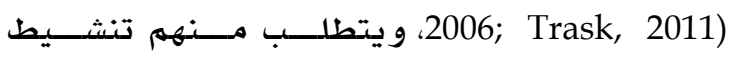

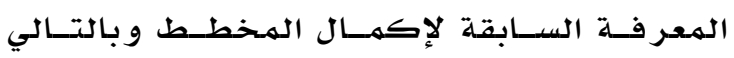
مساعدة الطلبـة في بناء وفهم العلاقات، و تحديسـد

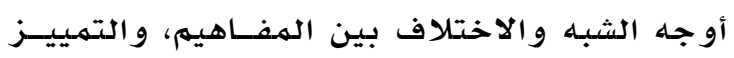
بين الخصائص الأساسية وغير الأساسية للمفهوم، و يزيد من تحصـيل الطلبـة و إتقـانهم للهفــاهيم ،(Nahampun \& Sibarani, 2014; Trask, 2011) ويزيد من دافعية الطلبـة خصوصداً الـذين لـديهم

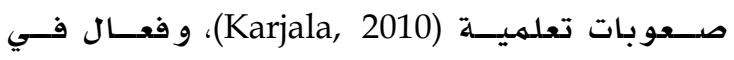
تدريس الهفاهيم المـركبـة و المهــردة، و تطــوير تعلهم ذي معنى (Ilter, 2015). تلدريل

ونظرا لهذه الميزات العديدة التي يتصف بها هذا

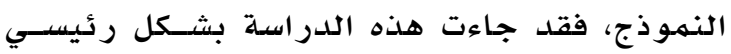

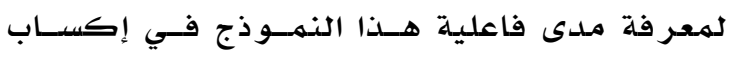

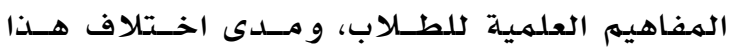
الاكتساب للمفاهيهم بـاختلاف التحصـيل السـابق ولقيه

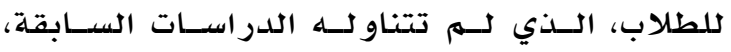
و الذي قد يفيد في الكشف عن مدىى مـلانٔمسة هــذا

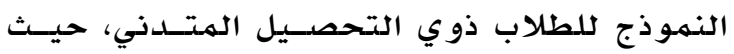

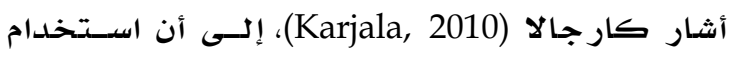

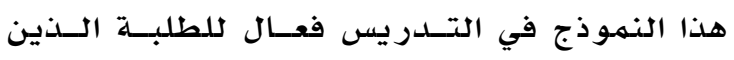
لديهم صعوبات تعلهية.

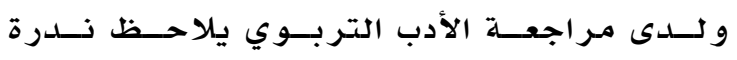
الدراسـات التي تنـاو لت أثـر التــدريس بـاسـتخدام

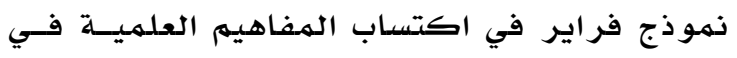

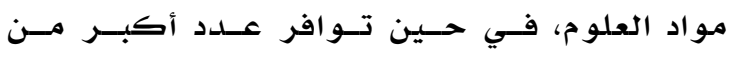

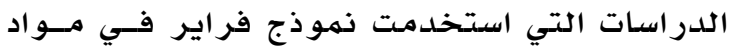

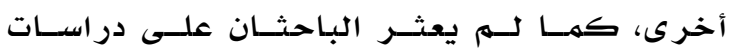
تناو لت اتجاهات الطلبة نحو نهوذذج فراير بشـكل

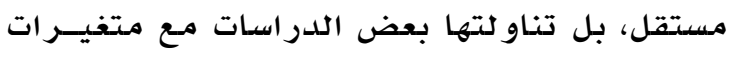
أخرى. ومـن الدراسات التي عثر عليها في مـهـال

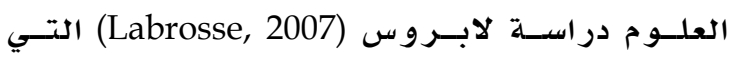
أجريت في أمريكا وهدفت إلى تحليل أثر تدريس دورس

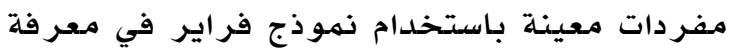

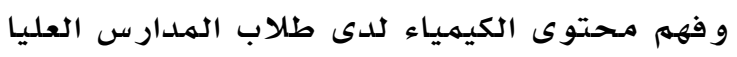

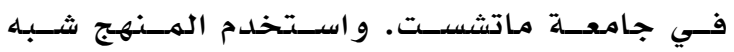


باستخدام نموذج التعر يف فقط، حيث طلـب مسـن

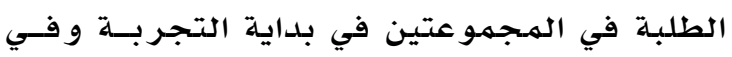

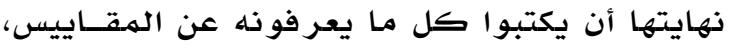

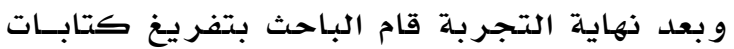
الطلبة القبلية و البعدية في نموذج أعده البـاحسث يتكون مـن: عدد مفاهيم الهقاييس التـي ذكر ذهــا

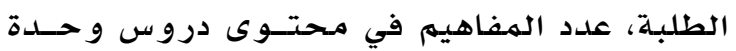

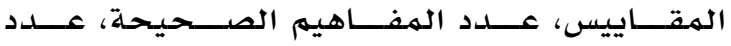

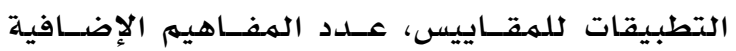
المدذكورة لكنها له تـدرس لهـهم بشـكل صسريح، وبعـد ذلــك حللــت البيانـات باسـتخدام اختبــار تحليل التباين المتعدد. و أشارت النتائج إلى تفوق المجمووعة التجر يبية على الضابطة، حيث سـجلوا

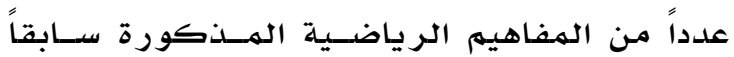
أكثر منـه في الهـجموعة الضـابطة، كهــا أثــار

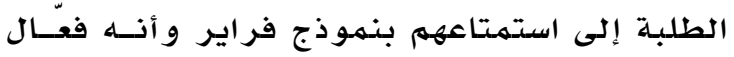
في تدريس المفردات الرياضية. و أجرى السـامعي (r..r) دراسـة هدفت إلى تعـرف أثر التدريس بحسب نهـوذج اكتســاب المفـاهيه

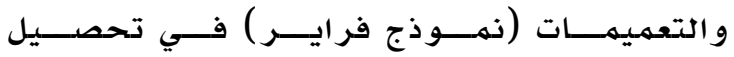
الرياضيات لدى تلاميذ الصف الرابع الأسساسي في

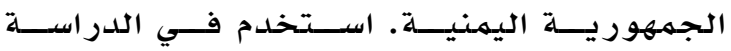

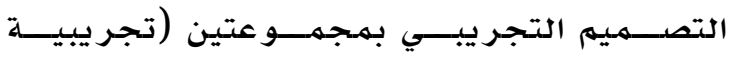

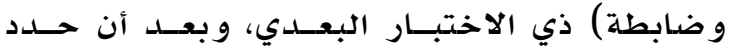

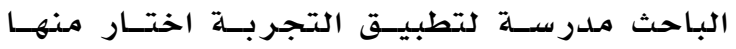

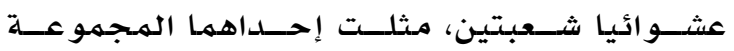

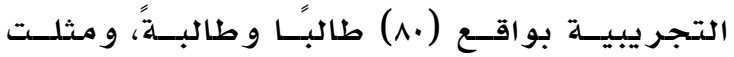

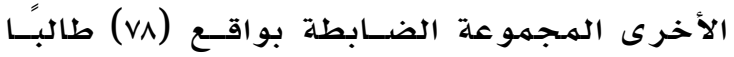

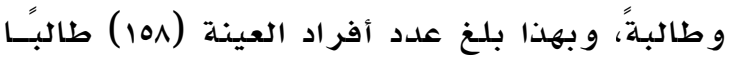

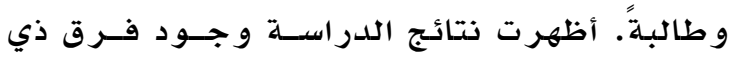
دلالة إحصائية عند مستوى دلالة ( اكتسـاب الهفاهيم بـين متوســ درجـات طلبــة

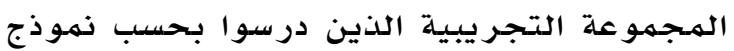
فراير ومتوسط درجات طلبة المهجمو عة الضابطة

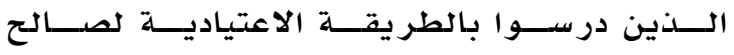

المهمو عة التجر يبية.

و أجرى فندي و غيدان (11)

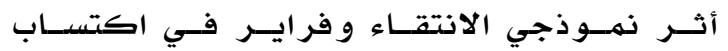
الهفاهيم النحوية في قواعد اللغلة العربية لـــى الـى

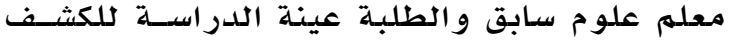

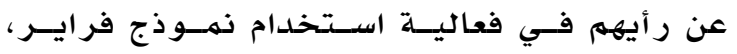
و أشارت النتائج في هذا الخصوص ولى إلى تفضـيلههم

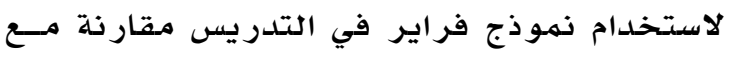

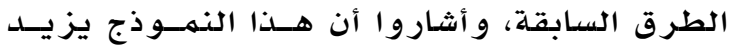

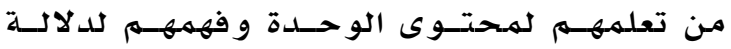

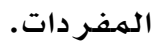

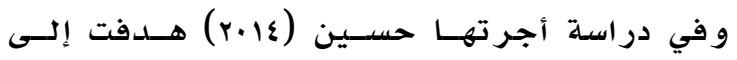

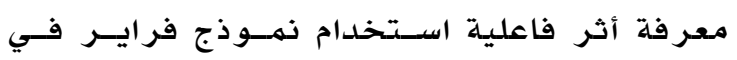
تصحيـح الأخطـاء الشـائعة دـدى طالبـات الصدف

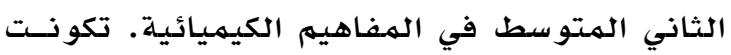

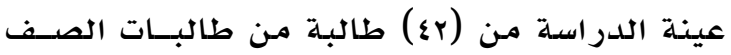

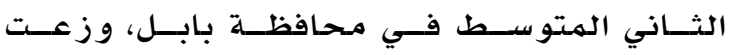
بالتساوي على مجمهـوعتين ضـابطة و تجربيبيـة. أظهرت نتــائج الدراسـة وجــود فـرق ذي دلادــة

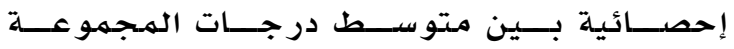
التجريبية اللاتي درسن على وفق نهـوذج فرايـر

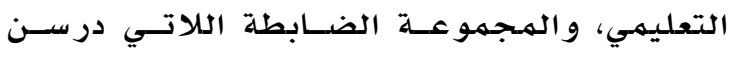
بالطريقة الاعتيادية في تصحيح الأخطاء الشائعة لصالح المسجموعة التجريبية.

أمـا الدر اسـات التـي أجـريت في مــواد أخــرى مثثل

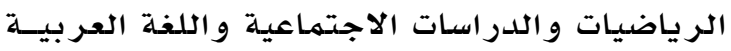

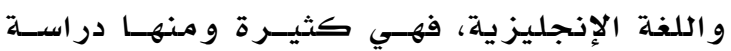

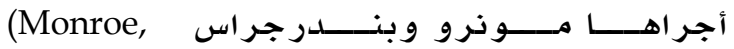
Brigham Young في جامعسة Pendergrass, 1997) هدفت إلى مقارنة أثـر اسـتخدام نهـوذجين فـي تدريس مفردات الرياضيات لطلبة الصف الر ابــع، الهـئ

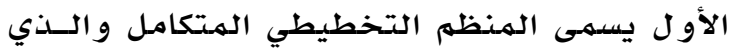

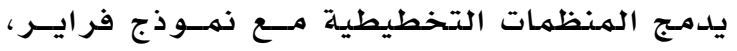

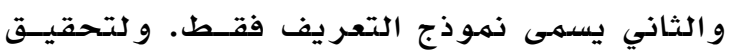

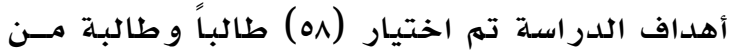
الصف الر ابع وتم توزيع الطلبة على مجهــوعتين

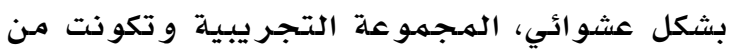

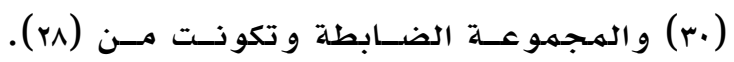
درست المجموعة التجر يبية الهفردات المتضـهمنة في وحدة المقاييس (تتكون من الدرووس: النظــام

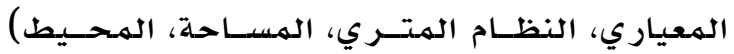

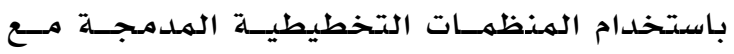
نهموذج فراير ، بينما درست المجمهوعـة الضــابطة 
المجموعتين مرة أخرى. و أشارت النتائج إلى أن

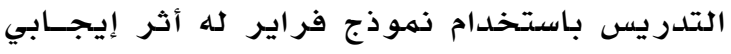
في تعلم المفردات مقارنة بالطريقة التقليدية.

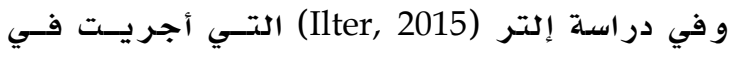

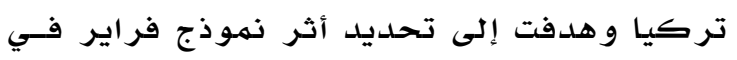
تطوير معرفة المفردات في الدراسات الاجتماعية

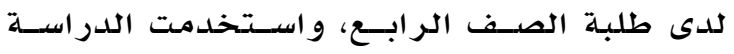

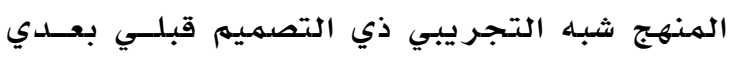

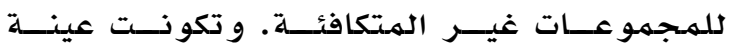

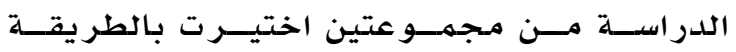

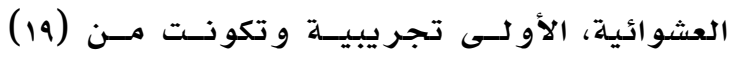

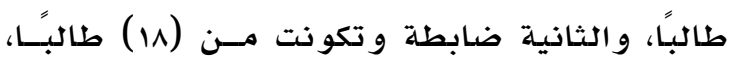

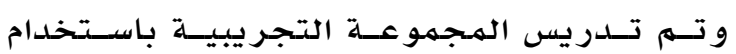

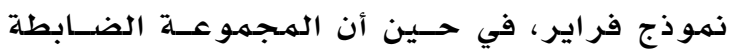

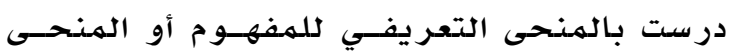

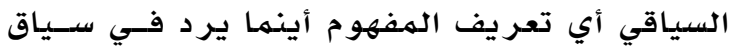

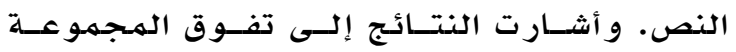

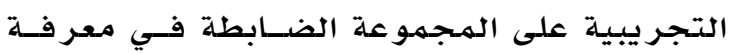

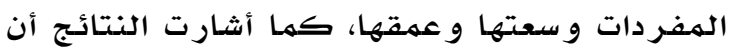

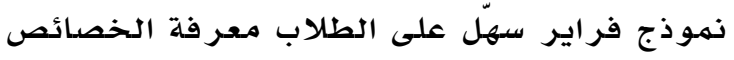

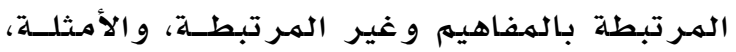

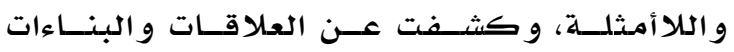

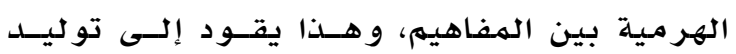
المعاني للمصطلحات بتنشيط المعر فة السابقة. و في ضوء عرض الدراسات السـابقة، يلاحسظ أن أن أنسات جميع الدراسات التي عثر عليها، أجريت في بلدان

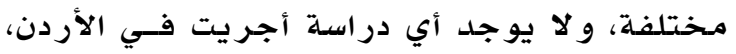

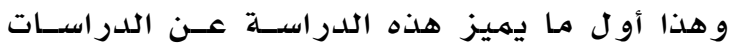

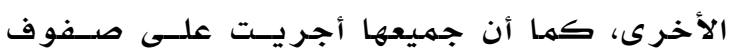

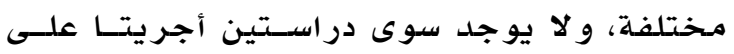

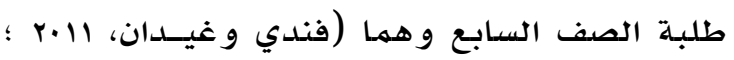
.(Trask, 2011

و يلاحظ أن معظم الدراسات أجريت في مجـالات

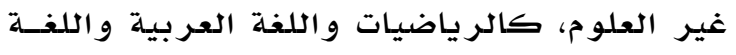

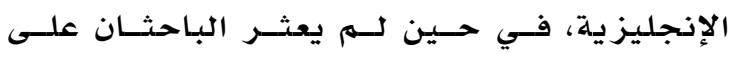

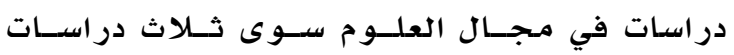
كانت في مجسـالي الكيميـاء والعلـوم الحياتيـة:

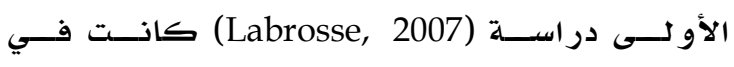

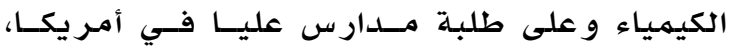

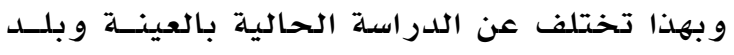

طالبــات الصـف الأول المتوســـ تكونـت عينـة

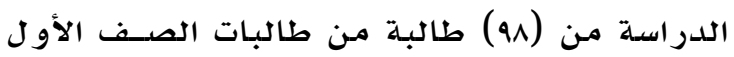

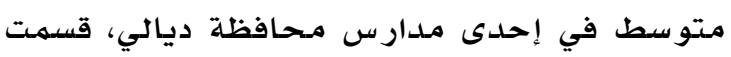

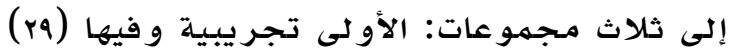

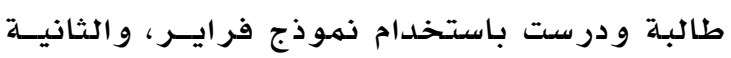

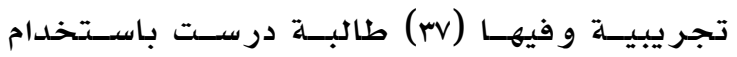

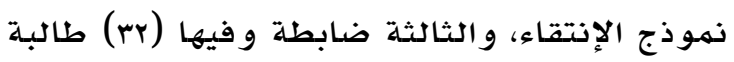

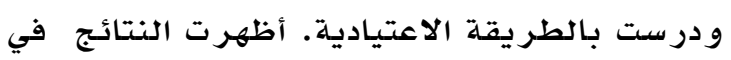

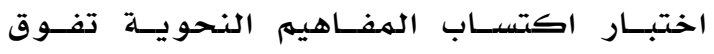

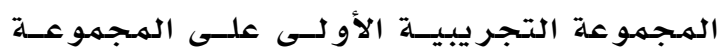
الضابطة في الاختبار البعدي.

وهدفت دراسة العزاوي (rابr) إلى دراسة فاعلية

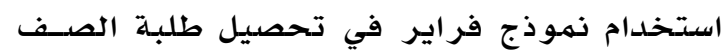

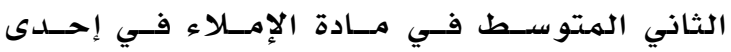

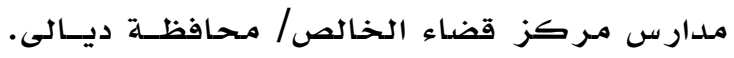

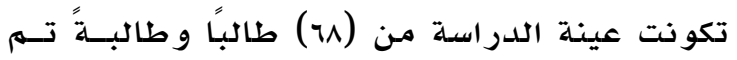

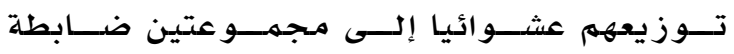

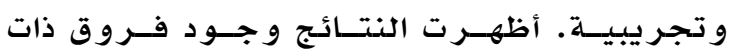

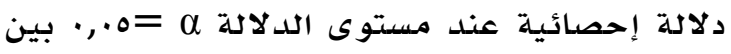

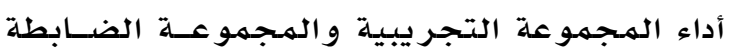

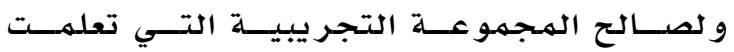

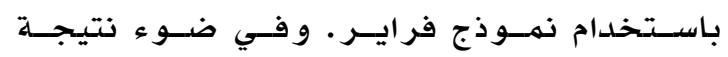

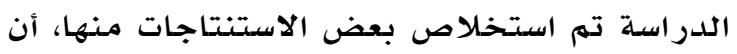

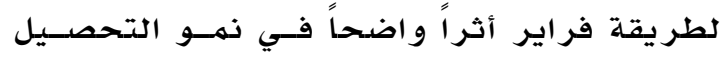

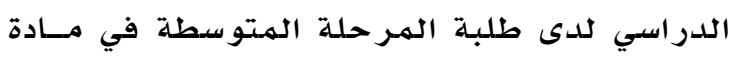
الإملاء.

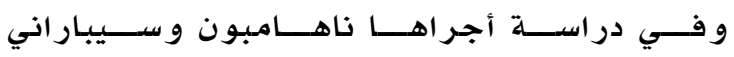
هدفت إلى اختبار (Nahampun \& Sibarani, 2014)

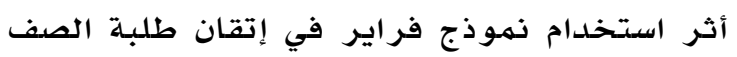

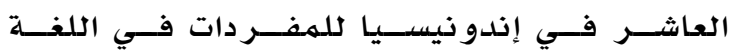

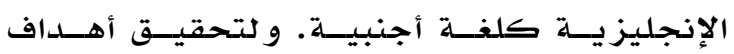

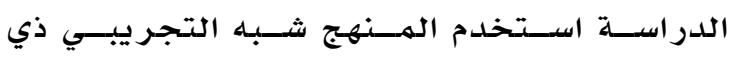
التصميم قبلي- بعدي للمجموعات غير المتكافئة،

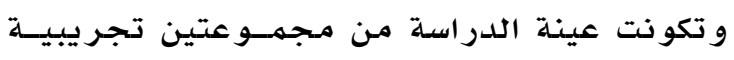

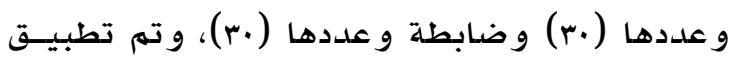

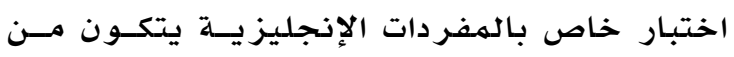

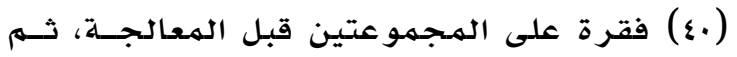

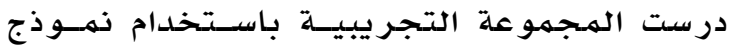

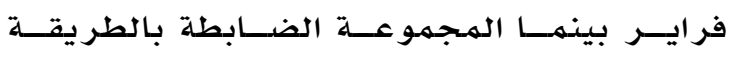

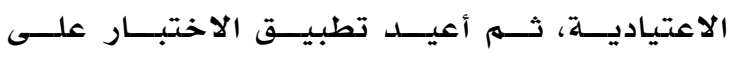




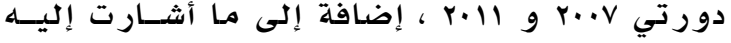

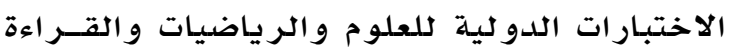
PISA

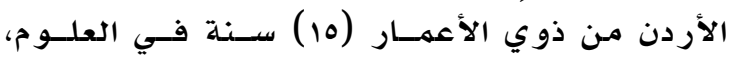

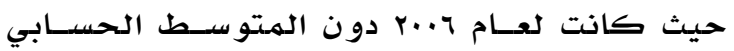
المعتمدد لمنظمهـة التعساون و التتنميسة الاقتصـادية و الذي يساوي (..0) درجة، وبرتبة (0ء) مـن أصل

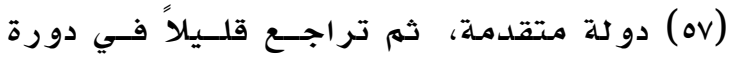

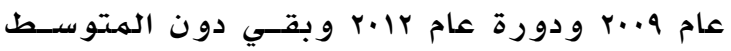

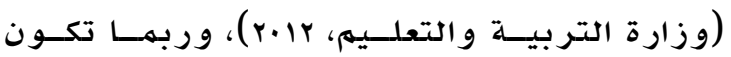

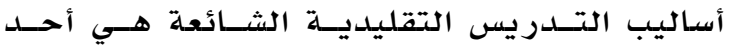

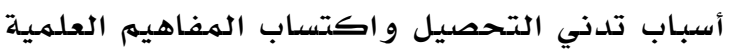
لدى الطلبة. لذا نادى التربويون بضرورة استخدام المعلمـين لنهــاذج وطر ائـق و اســتر اتيجيات تـــر يس تتــيح

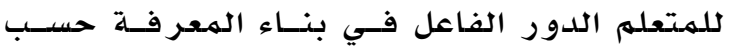
فهمه الخاص، بشكل نشط و فعال ذاتياً واجتمـاعيًا،

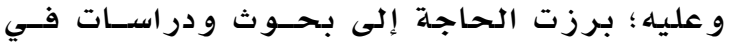

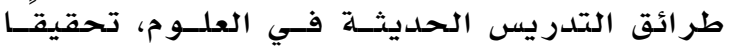

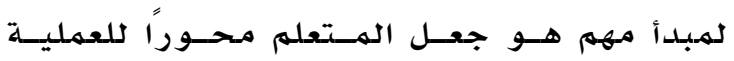
التعليهية التعلمية. و انطلاقةًا مما سبق جــاءت هــذه الدراســة لإلقتـاء الضوء على أثر استخدام أحد أسـاليب التـدريس

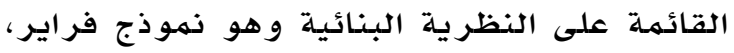

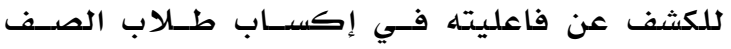
السابع للمفاهيهم العلمية بشكل سليه، و الكشف عن إنه اتجاهاتهم نحو اسـتخدام هـذا النهـوذذج، و يهـــن تحديد ذلك من خلال الإجابة عن الأسئلة الآتية: السؤال الأول: هـل يختلــف اكتســاب الهفـاهيم

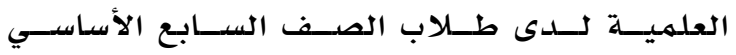
باختلاف كل من:

طريقــة التــدريس (نمـــوذج فر ايــر ، الطريقـــة الاعتياديــة)، و تحصــيلهم الســـابق فــي العلـــوم

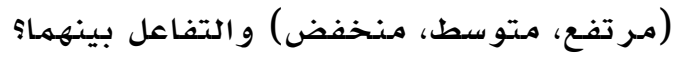
السؤال الثاني: ما اتجاهات طلاب الصــف الســابع الأسـاسي نحو استخدام نموذج فراير في تعلمهـم

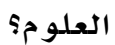

اللدر اســة و مـجالهـا التخصصسي، و الثانيسـة دراســة

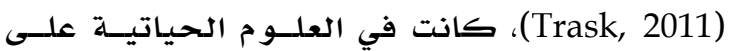
طلبة الصف السابع في أمـريكا، وهي بهـذا تتفـق الق

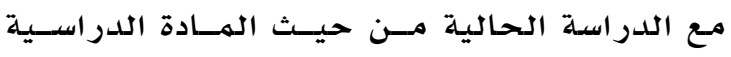

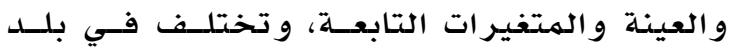

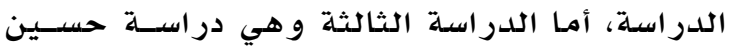

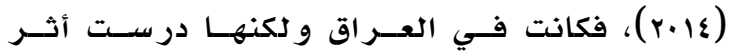
نهـوذج فراير على تصحيح الأخطاء الشـائعة فـي الكيمياء، و هي بهذا تختلف عن الدراســة الحساليسة في عينـة الدراسة وبلــــ الدر اســة و فـي المتغيـر

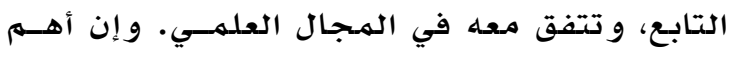

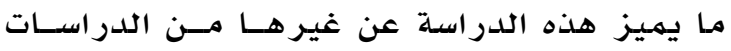
السابقة، أنها تعتبر الأولى من ذوعها في الأردن -

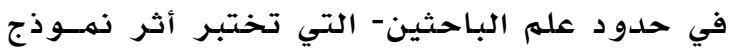

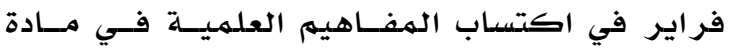
العلوم للصف السابح في وحدة تصـنيف الكائنـات الحية. المانم.

\section{مشكلة الدراسة و أسئلتها}

في ضوء خبرة البـاحثين فـي الميـدان التربــوي

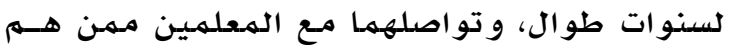

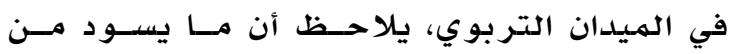
طرق تدريس في النظام التعليهـي توصــف بأذهـا

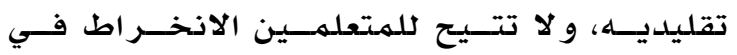

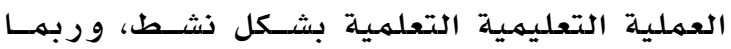
يكون هذا أحد الأسبـاب الرئيســة لتسدني تحصـيل

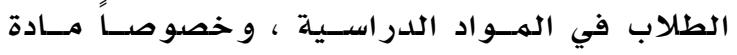

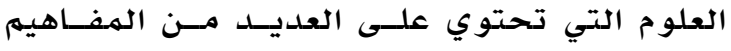

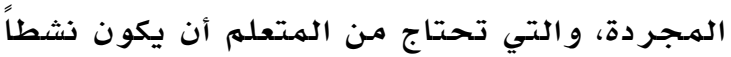
و بانياً للهعر فهة.

و مهما يـلل علـى ذلــك مـا أشــارت إليسـه بعـض

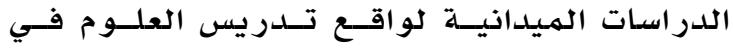
الأردن من تدني مستوى تحصيل الطلبــة وتـدني

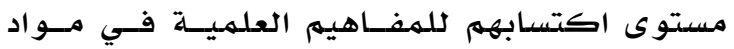

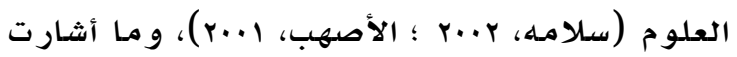

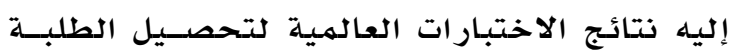
في الرياضيات و العلوم (TIMSS)، التي أجريت في

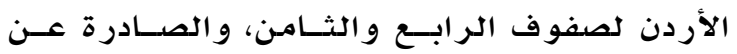
الهـركز الوطني لتتمية القوى البشرية من تـدئ

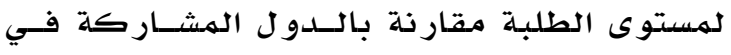


التربويون منذ عقود، والتي تركز على التئي الهتعله وكيفية اكتسابه للمعرفة. تثري الدراســة الأدب التربـوي المتعلــق

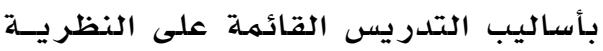

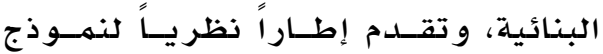

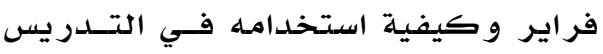

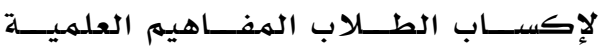

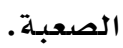
الجانب العملي

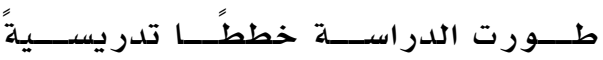
باستخدام نموذج فراير التدريسي يمكــن أن يستفيد منها المعلمون عند التخطيط

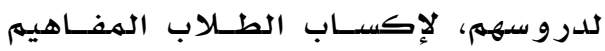
العلميلة التي تشتر ك مـع بعضها في بعض الحض الخصائص الأسساسية. طورت الدراسة اختبـاراً لقياس اكتســاب الهفاهيهم العلميـة يمكن أن يسـتفيد منــهـ

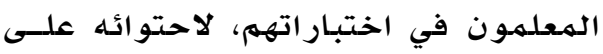
مهموهات ذات فعالية عاليةٍ. طورت الدراسـة أداة لقيـاس الاتجاهــات

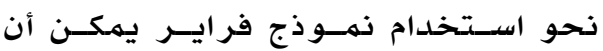
يستفيد منها الباحثون فـي تطوير هــا أو تقنينها.

محددات الدراسة وحدودها يتقيد تعميم نتائج الدراسة بالمـحددات والحسدود

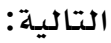

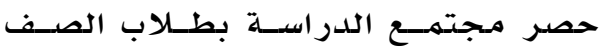

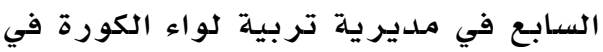

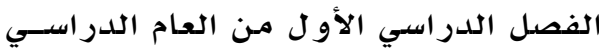
$. r+10 / r+18$

اقتصرت المــادة التعليميـة علـى وحسـدة

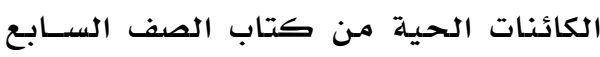
لهــا تحتويسـه علــى مفــاهيم تصــنيفية

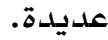
مــدى صدسدق و ثبــات اختبــار المفــاهيم

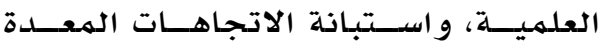
لأغر اض الدر اسلة.
السؤال الثالث: هل توجد علاقــة ارتباطيـة بـين اكتسـاب طلاب الصف السـابع الأسـاسـي للهفــاهيم العلمية و اتجاهاتهم نحو التعلهم باستخدام نهـوذذج فر ايرى

\section{فر ضيات الدراسة}

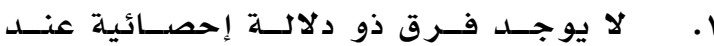

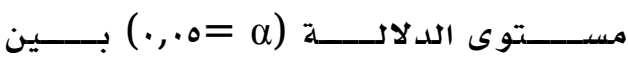

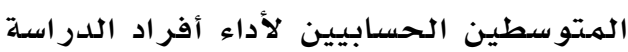

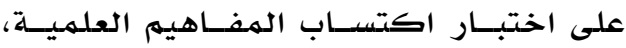

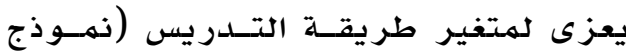
فر اير ، الطريقة الاعتيادية).

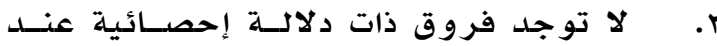

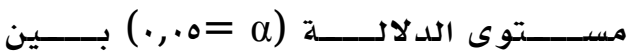

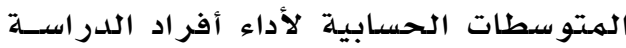

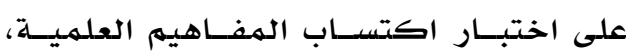
تعزى لمتغير التحصيل السـابق في العلــوم

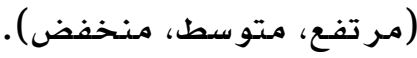

r. لا توجلد فروق ذات دلادــة إحصــائية عنــد

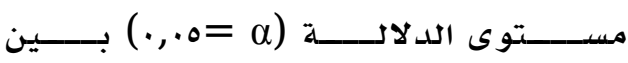

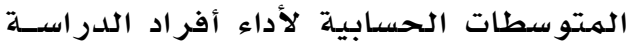
على اختبــار اكتسـاب الهفـاهيم العلميـة،

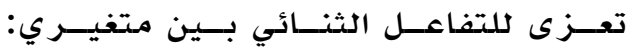

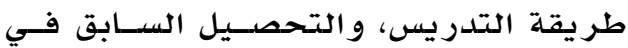
العلوم. - العزم

ع. لا توجــــ علاقـــة ارتباطيـــة ذات دلادلــة

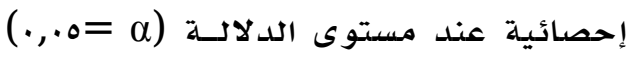

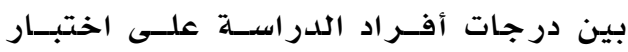

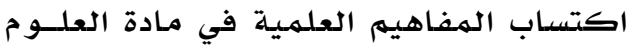
ودرجاتهم على مقياس الاتجاه نحو التعلهم باستخدام نموذج فر اير •

أهمية الدراسة

تتهثل أهميـة الدراسلة في جانبين؛ جانـب نظـري وجانب عملي كما يلي: الجانب النظري: استخدمت الدر اسـة نمو ذجاً تدريسيًا قائهماً

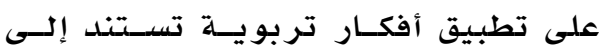

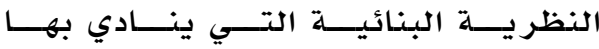




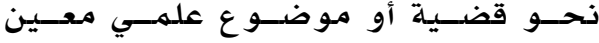

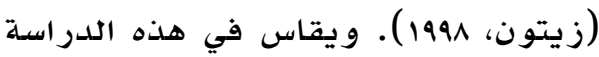
بالعلامسة التي يحصل عليها الطـلاب مسنـ

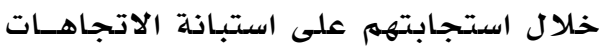
نحو استخدام نهـوذج فرايـر التدريسـي

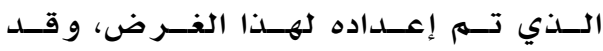

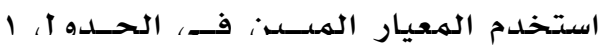
لتحديد الاتجاه.

جدول

المعيار الإحصائي لتحديد لاتجاه

\begin{tabular}{|c|c|c|}
\hline مستوى الاتجاه & الاتجاه & المتوسط الحسابي \\
\hline منخفض & سلبي سلب & 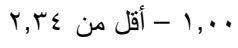 \\
\hline متوسط & محايد & ع r,r - أقل من VT,T \\
\hline مرتفع & ايجابي & $0, \cdots-r, T V$ \\
\hline
\end{tabular}

\section{الصف السابع:}

هو السنـة الدراسـية الســابعة فـي سـلمه التعليه في النظام التربوي الأردني الذي يبدؤه الطلاب في عمر ست سـنـوات فـي الصف الأول و ينتهـي فـي سـن الثامنــة عشر في الصف الثاني الثانوي.

\section{الطريقة والإجر اءات}

فيمــا يلــي و صدف مفصـل لمنهجيــة الدراســية و مجتمعها و عينتها، و إجر اءاتها، و أداة الدر اسلة .

\section{منهج اللدراسة وتصميمها}

بهدف الإجابة عن أسئلة الدراسـة استخدم الهـنهج

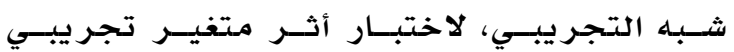

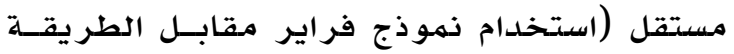
الاعتيادية في التدريس) في متغيرات تابعة وهي:

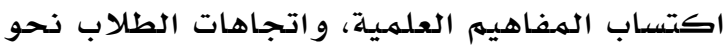
نموذج فراير، وقد أدخل متغير التحصيل الســابق

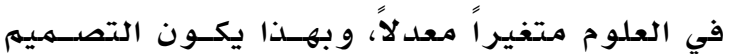
المستخلدم هو تصميهم قبلسي-بعسدي لهمجمـوعتين غير متكافئتين و بالشكل الآتي:

EG: O $\times$ O

$\mathrm{CG}: \mathrm{O}-\mathrm{O}$

حيث إن O O: اختبـار اكتساب المفـاهيم العلميـة، X
مدى جديــة الطــلاب فـي الإجـابــة علـى

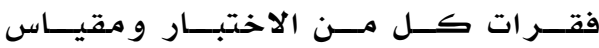
الاتجاهات.

مدىى مـلاءمـة الإجـر اءات المســتخدمـة فـي التدريس حسب نموذج فراير التدريسي.

المصطلحات والتعريفات الإجر ائية نموذج فراير التدريسي:

استراتيـية تعليميـة تقـوم علـى تحديسـد أوجـهـ الشبـه والاختلاف بين المفهوم الجديد و المفاهيم لهيد الأخرى التـي بحــوزة الهـتعلهم، ويـتم فـي هـــا

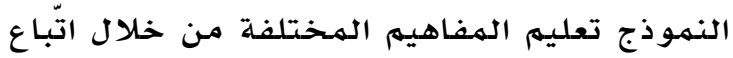

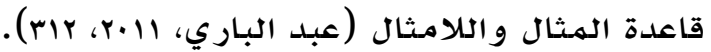

\section{التحصيل السابق:}

- علامة الطالب فـي مــادة العلــوم فـي

الصف السادس بعد تحويلها مــن (0.0)، وقد صنفت إلى ثلاثة

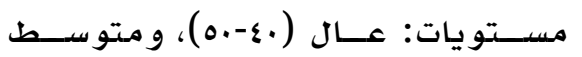

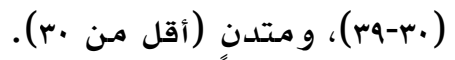

اكتساب المفاهيم العلمية: عر فها ديفز

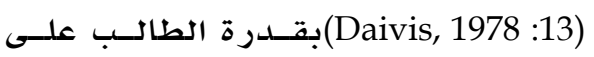
التمييز بين أمثلة المفهوم من لا أمثلته، رابها وتحديد الخصــائص و الشــروط الكافيـة ليكون أي مثثـال هـو مثــال علــى ذلــك وفيك

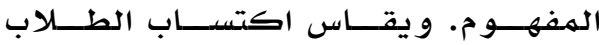

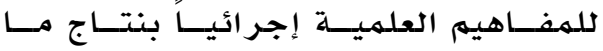

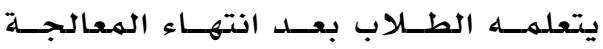
التجر يبيـة، ويعبـر عنــه بالعلامسـة التـي

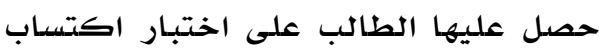
المفاهيم العلميـة فـي وحسدة الكائنــات

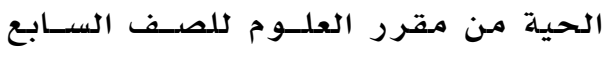
الأسـاسي في العام الدراســي 10 إبم الــذي

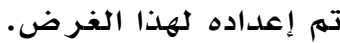

الاتجاهات نحو نموذج فراير التدريسي:

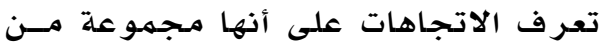

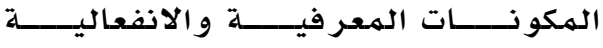
و السلوكية التي تتصل بـاستجابـة الفــرد 
(Frayer et al, 1969)، حيث يركز هـذا النـهـوذج على الخصائص الأساسية للمفهوم و على الأمثلـة التي تنتمــي للمفهـوم و الأمثلــة التسي لا تنتمهـي للمفهوم (لا أمثلة)، و التمييز الدقيق ولهيق بين المثـال

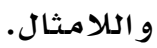

أما المفاهيم الرئيسة في الوحدة فقد بلغ عسددها

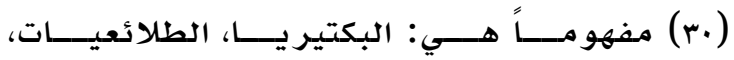

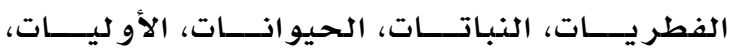

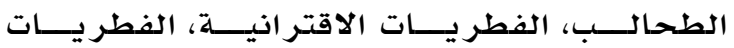

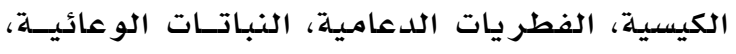

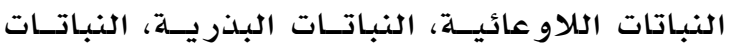

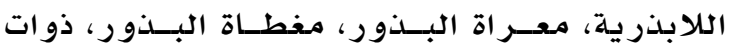

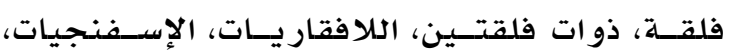

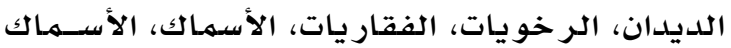

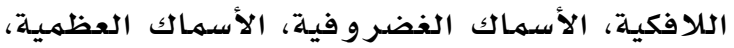
البر مـائيات، الزو احف، الطيور، الثديات.

تم تدريس هذه المفاهيم للمسجموعة التجريبية حسب الخطوات الرئيسلة الآتية:

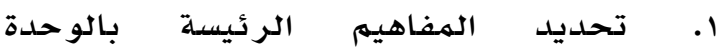
و علاقتها بالمفاهيهم المر تبطة بها.

r. اختر أحد المفاهيم المـراد تقديمه للطلبـة مـر اعيا التسلسل المنطقي للمفاهيه. r. ارسم المخطط الرسومي لنموذج فراير على السبورة.

؟. أكتب اسهم المفهوم المرراد تلدريسـ بوسط المخطط.

0. اطلب من الطلبــة دراسـة الجـزءء الخــاص بالمفهوم مـن الكتاب (بضع دقائق).

7. اطلب من الطلبة تقديم تعريف للمفهوم

واكتب التعريف الصحيح على السبورة الصبه

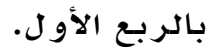

V اطلب من الطلبة ذكر الخصائص الأساسية

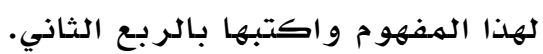
^. اطلب من الطلبة ذكر أمثلة على الهفهوم

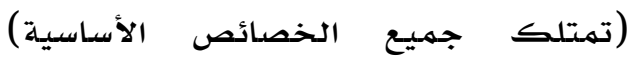
و اكتبها بالربـع الثالث.

\section{متغير ات الدراسة}

اشتمل تصميهم الدراسلة على المتغيرات الآتية: 1. المتغير المستقل: طريقة التدريس (وولهـ

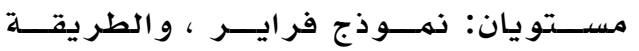

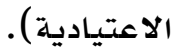

ץ. متغير تصنيفي معسدل: التحصديل الســابق

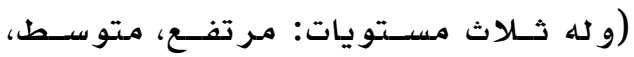
منخفض) r. المتغفيـر ات التتابعــة: الكتســاب المفـــاهيم العلميــة، اتجـاهـات الطـلاب نحسو نمــوذج فر اير - ن مجتمـع الدراسة وعينتها

تكون مـجتمـع الدر اسـة مـن جميـع طـلاب الصـف

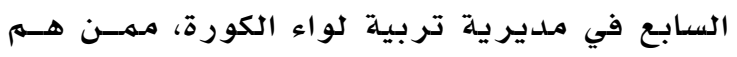
على مقاعد الدر اسـة في الفصل الدراسي الأول مـن

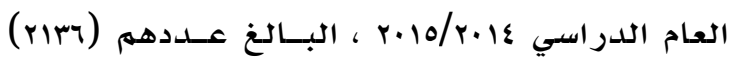

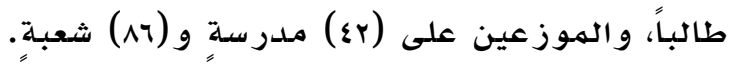

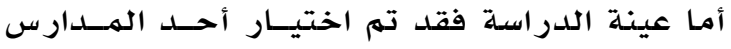

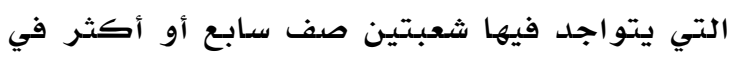

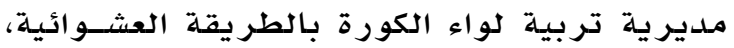
و كانت مدرسة سهوع الأساسـية للبنـين، و التـي

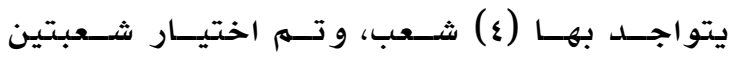

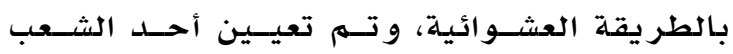

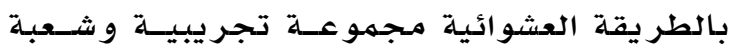

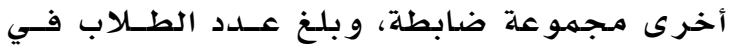

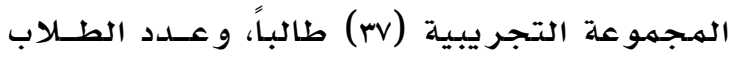
في الهـجمو عة الضابطة (مr) طالباً. مواد و أدوات الدراسة أولأ: المادة التعليهية:

اختيرت وحدة تصنيف الكائنات الحية من كتـاب الصف السـابع الأساسـي للفصـل الأول مــن العـام

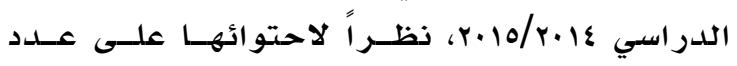

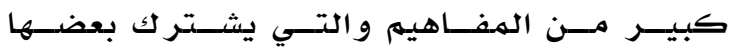

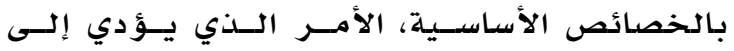

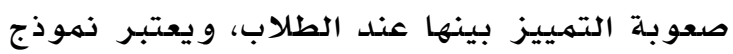

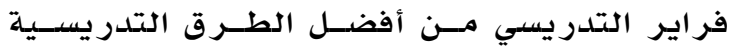

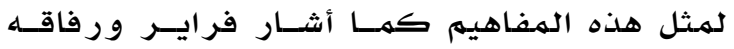




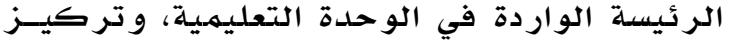

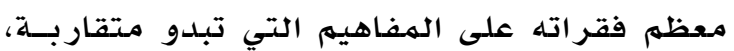
أي تمتلك بعض الخصدائص المشتر كة اهم. صــدق الاختبــار: للتحقـق مــن صســق الاختبـار الظاهري، أرفـق الاختبــار مــع قائمسـة الهفـاهيم الرئيسـة في الوحدة الدراسية و أهدافها التعليميهة، و عر ضت على مجمموعة مـحكمين (معلمــي أحيـاء، أعضــاء هيئسـة تـلـريس فـي تخصصسي المنــاهـج و القياس و التقويه)، و طلب منهم إبداء ر أيهم فـي

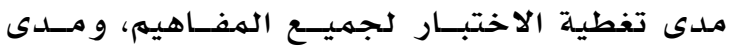
ملاءمـة البدائل في كل فقرة، ووصـياغة الفقـر ات ووضوحها و صحتها من الناحية العلمية واللغوية،

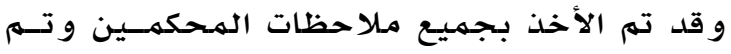
إجراء بعض التعديلات على فقر ات الاختبار. و للدى تطبيق الاختبـار على عينـة اسـتطلاعية مسن

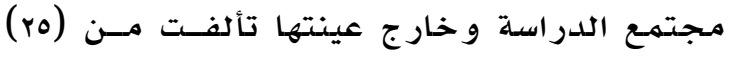

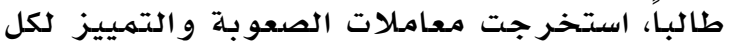

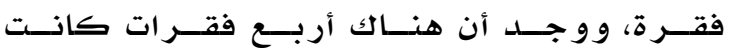

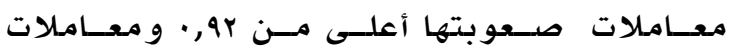

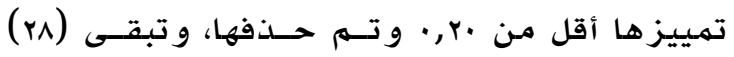

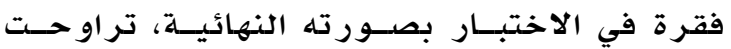

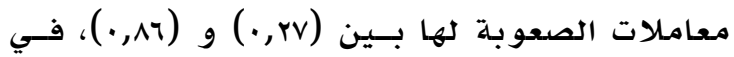

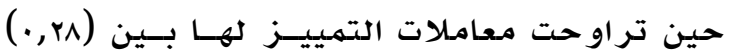

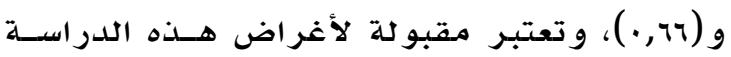

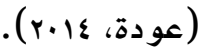

ثبـات الاختبــار: للتحقــق مــن ثبــات الاختبــار استخدمت علامات طلاب العينة الاستطلاعية، وتم تقدير ثبات الاتساق الداخلي، بين فقرات الاختبار باستخدام معادلة كرونباخ ألفـا، وبلغـت قيمتــهـ

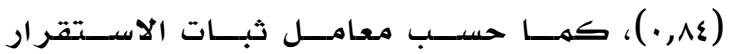

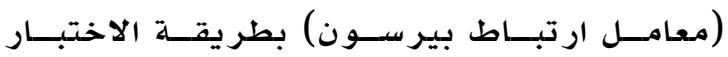

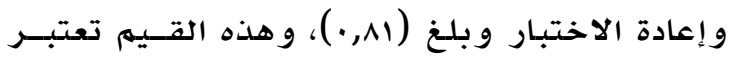

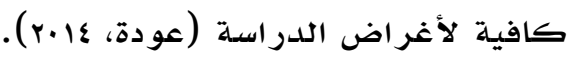
تصحيح الاختبار: أعطيت الإجابة الصحيحة لكسل

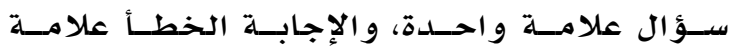

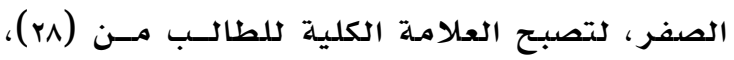

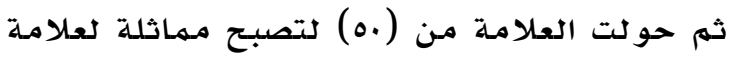
التحصيل السابق.
9. اطلب من الطلبة ذأكر لا أمثلة على

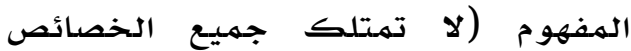

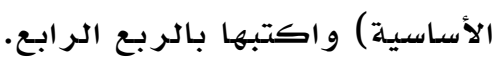
•1. قسهم الطلبة إلى مجمو عات ثنائية وزو دهـا بنماذج فارغة أو على دفتر الطالب وكرر

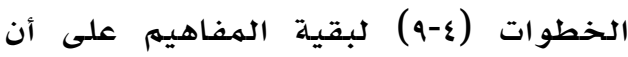

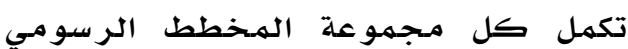
لوحدها.

بعد عمل كل مخطط ناقش نتائج الطلبة .11 و قومها على السبورة وارسه المـخط الر سدو مي السـليهم.

rا. قدم عدد من الأمثلة واللاأمثلة مختلطة

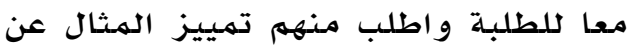

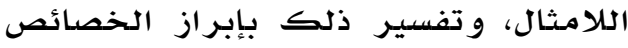
الأساسية التي يفتقر إليها اللالامثال. و الشكل r الآتي يمثل أحد المفاهيم التي درست باستخدام الخطوات السـابقة لنهموذج فراير:

\begin{tabular}{|c|c|}
\hline 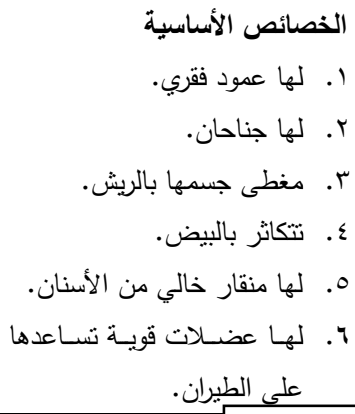 & 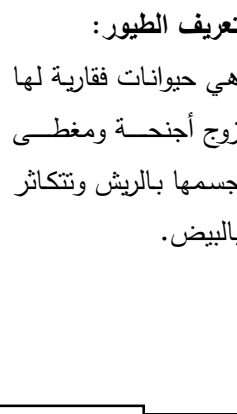 \\
\hline \multicolumn{2}{|c|}{ الطيور } \\
\hline \multirow[t]{2}{*}{ ليست أمثلة على الطيور } & مثلة على الطيور \\
\hline & العصفور \\
\hline ا ـ. الخفاش & الحمام \\
\hline r. . الفراثة & الإوز \\
\hline r. الذباب & النسر \\
\hline ع. الجراد & البطريق \\
\hline ه. الناموس & النعامة \\
\hline
\end{tabular}

شكل r: مخطط رسومي لاكتساب مفهوم الطيور باستخدام نموذج فراير

ثانياً: اختبار اكتساب المفاهيم العلمية بناء الاختبار: تكون الاختبار بصورته الأولية من

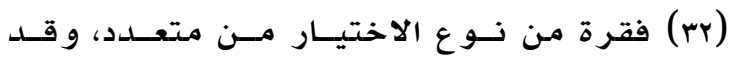

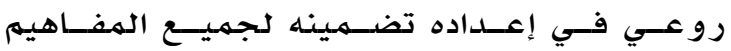


حددت المشكلة و أسئلتها و فر ضيتها.

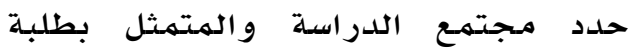

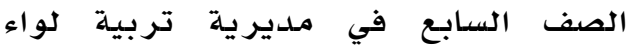
الكورة، ثم اختيرت أحد المدارس مـ بين

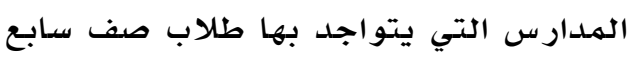

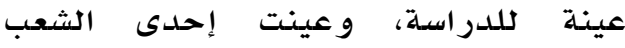

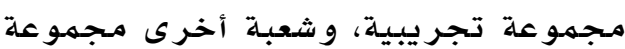
ضابطة بالطريقة العشو ائية. r. حددت المادة التعليمية بوحدة الكائنات

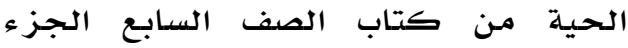

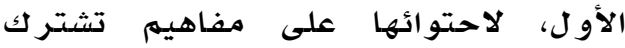

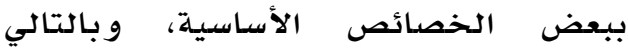

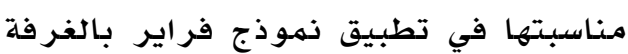
الصفية. أعدت الخطط التدريسية لمعلم العلوم

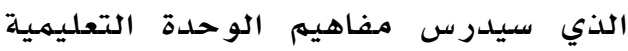

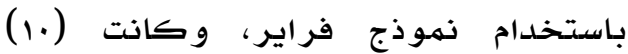
خطط، تتضمن كل خطة (r) مفاهيم رئيسلة.

ه. درب الهعلهم على استخدام هذا النهوذج

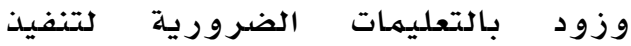
التدر يس.

أعد اختبار اكتسـاب المفاهيم العلمية، وتم

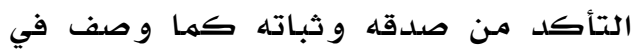
أدوات الدر اسـة.

V. أعد مقياس الاتجاهات نحو التعلم

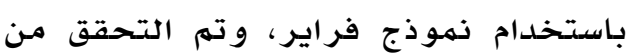
صدقه و وثباته كما و وصف في أدوات

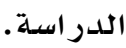

طبق اختبـار اكتساب المفاهيم القبلي في

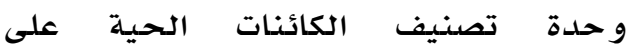

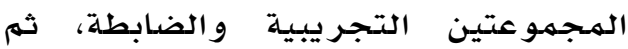
صححت الأوراق ور صدين الهوت علامـات الطلبة. تم البدء بتنفيذ الخطط التدريسية من قبل المعلم على المجموعة التجريبية في البـاء

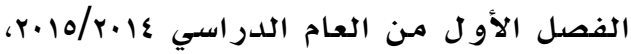

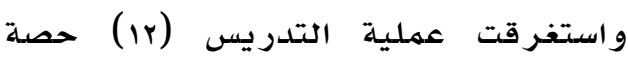
دراسية، في حين أن المجهموعة الضابطة

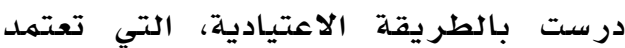

ثالثاً: مقياس الاتجاهات نحو الـتعلم باسـتخدام نموذج فراير

بناء المقياس: تم بناء المقياس بالاستعانة ببعض

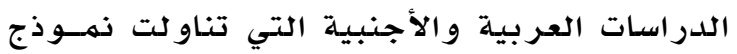
فراير و مسميزات استخدامهه و أثره في المتعلهم من فن جميع جوانسب النهـو كدر اســات (زيتــون، 1991؛ ،(Pendergrass, 1997; Trask, 2011; Ilter, 2015 و قد اعتمدت طريقة ليكرت لقياس الاتجاهات ذات

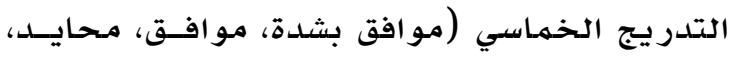

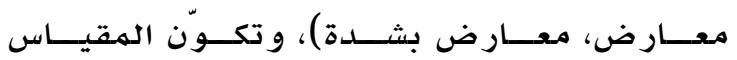

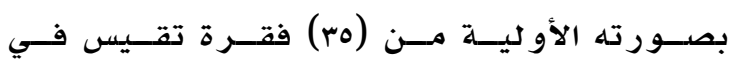

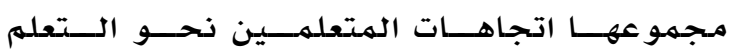
باستخدام نموذ ج فر اير .

صدق المقياس: تم التحقق مسـن صسـدق الهقيـاس بعرضه على مجهموعة من المحكمين المتخصصين

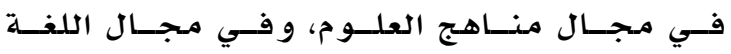

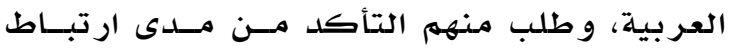

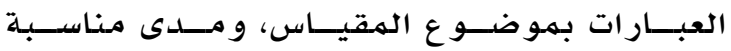

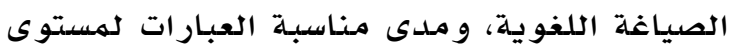
الطالب. و في ضــوء آراء الهـحكهـين تــم تعـديل

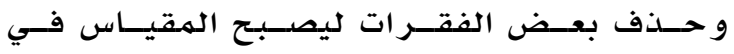
صور ته النهائية مكون من (بr) فقرة الترة

ثبات المقياس: تم التحقق مــن ثبـات المقيـاس، بتطبيق المقياس على عينة استطلاعية بلغ عددها

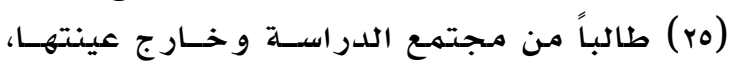

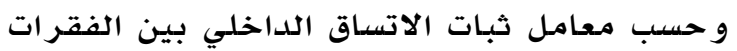
باستخدام معادلة كرو نباخ الفـا، وبلغــت قيمتسـه

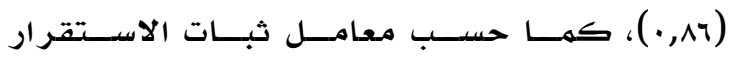

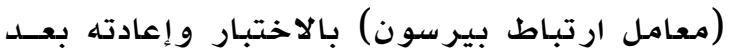

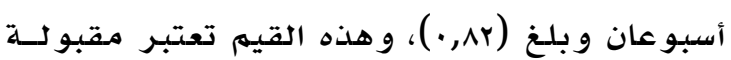

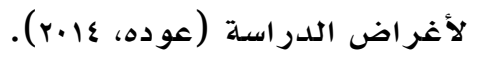
تصحيح المقاييس: صححت الفقـرات الإيجابيـة

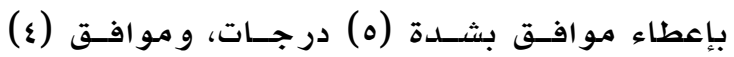

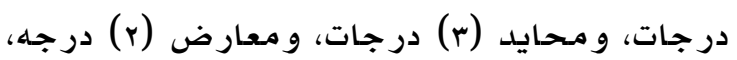

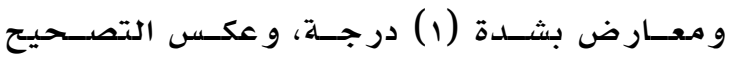
للفقر ات السلبية. خطوات تنفيذ الدراسة تم تنفيذ الدراسة و فق الخطوات الآتية: 
العلمية، يُعزى لمتغير طريقة التـدريس

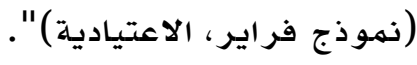

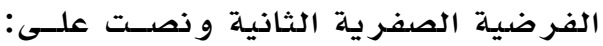
"لا توجد فروق ذات دلادلة إحصائية عند

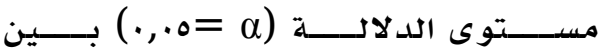

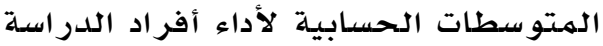

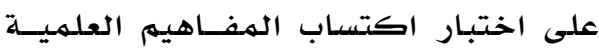

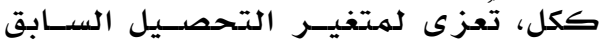

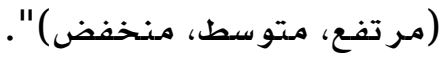

الفرضية الصفرية الثالثة و نصست علــى:

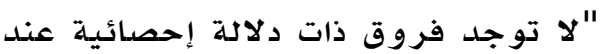

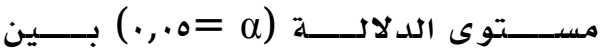

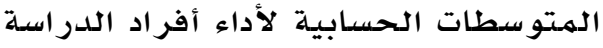

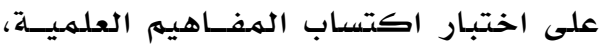

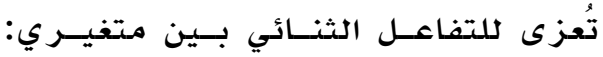
طريقة التدريس، و التحصيل السـابق". و للإجابــة عــن هــذا السـؤال و التحقــق مــن

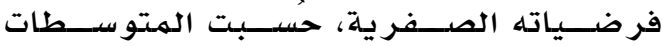

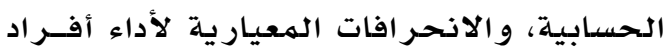
الدراســة علـى اختبـــار اكتســاب الهفــاهيم

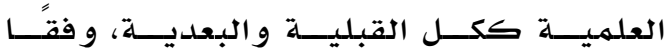
لمتغيــري: طريقـــة التـدريس، و التحصــيل السابق، وجلدول r يبين ذلك.

يتبين من جدول r وجود فروق ظاهرية بين

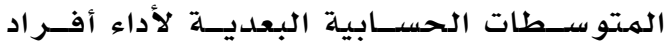
الدراســة علــى اختبـــار اكتســاب المفــاهيم

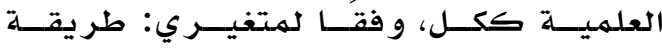

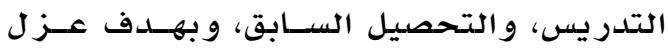

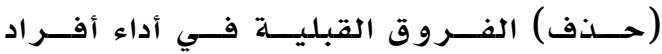
الدراســة علـى اختتبــار اكتســاب الهفــاهيهم

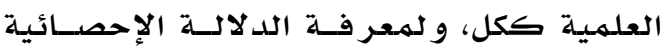
لتلك الفــروق الظاهر يــة وفقــا لمتغيـري:

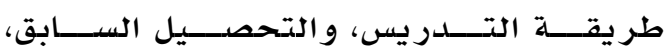
والتفاعل بينهما؛ فقد استخدم تحليل التباين الثنــائي المصـاحب (Two Way ANCOVA)،

$$
\text { كما هو مبين في جدول }
$$

على الشرح و التوضيح من قبل المعلهم

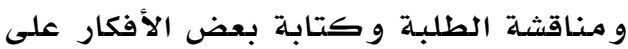

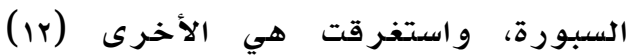
حصدة در اسية. بعد انتهاء التدريس طبق اختبار اكتسـاب

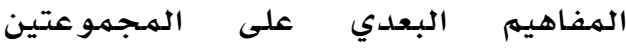
التجريبية والضابطة، و وطلب من كل

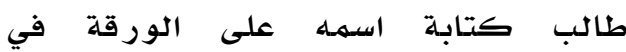

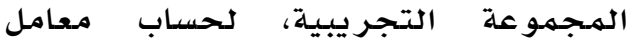
الارتباط، ثم صححت الأوراق ورصده اتهرت العلامات.

11. طبق مقياس الاتجاهات نحو التعلم

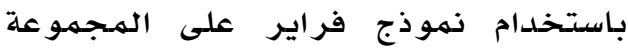

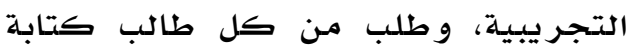
اسهمه على الهقياس (من أجل حسـاب معامل

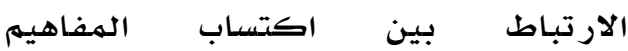
والاتجاهات)، ثم صححت الأوراق وردياه

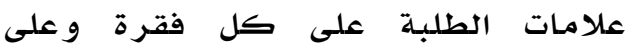
المقياس الكلي.

rا. فرغت البيانات وأدخلت في ذاكرة

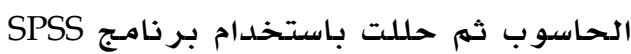

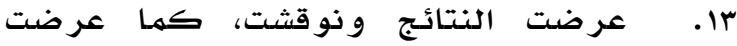
التوصيات في ضدوء النتائج.

\section{نتائج الدراسة ومناقشتها}

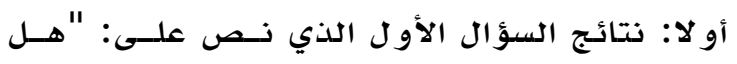

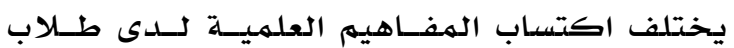
الصف السابع الأساسي باختلاف كل مـن: طريقة التدريس (نمو ذج فراير، و الاعتيادية)، و تحصيلههم الهئه

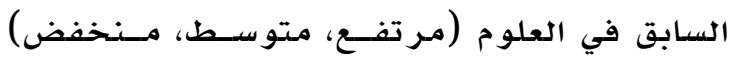
و التفاعل بينهماء التوي العلوم

و قد انبثق عن هذا الســؤال الفرضـيـات الصـفرية

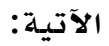

الفر ضية الصفرية الأو لى و نصست علـى:

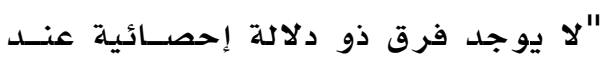

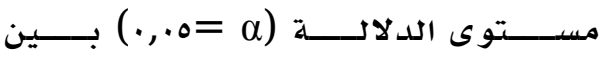

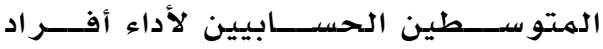

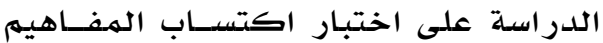


جدول ra

المتوسطات الحسابية، والانحرافات المعيارية لأداء أفراد الدراسة على اختبار اكتساب المفاهيم العلمية ككل القبلي والبعدي، وفقا

\begin{tabular}{|c|c|c|c|c|c|c|}
\hline \multicolumn{2}{|c|}{ التقدير البعدي } & \multicolumn{3}{|c|}{ التقدير القبلي } & \multirow{2}{*}{ التحصيل السابق } & \multirow{2}{*}{ طريقة التدريس } \\
\hline الانحراف المعياري & المتوسط الحسابي & الانحراف المعياري & المتوسط الحسابي & العدد العد & & \\
\hline$r, 1 \varepsilon$ & YI,IV & 1,01 & Q & v & منخفض & \multirow{5}{*}{ نموذج فراير } \\
\hline r,ov & $r \cdot, N r$ & $r, 11$ & $1 \varepsilon, r 4$ & rr & متوسط & \\
\hline 1, & $\varepsilon \cdot, O V$ & I, I & $19, \ldots$ & 9 & مرتفع & \\
\hline $7, \vee \vee$ & TI,11 & $r, 0 \leqslant$ & $1 \leq, \varepsilon r$ & rv & الكلي & \\
\hline$r, 10$ & MI,OV & $r, \cdot \varepsilon$ & $\mid r, \wedge T$ & 7 & منخفض & \\
\hline$r, 07$ & 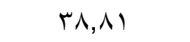 & $r, 0$. & $10,0 \mathrm{r}$ & rr & متوسط & \multirow{3}{*}{ الاعتيادية } \\
\hline$r, \varepsilon \vee$ & $\sum 1, \wedge 9$ & r, rv & $|\wedge, 1|$ & v & مرتفع & \\
\hline$\varepsilon, r \leqslant$ & rᄉ, 19 & $r, 71$ & 10,70 & ro & الكلي & \\
\hline $0, \vee \wedge$ & $Y ૫, V V$ & r,Or & II, & $1 \pi$ & منخفض & \multirow{4}{*}{ الكلي } \\
\hline $0, \cdot 1$ & $r \varepsilon, V T$ & r.q. & $1 \varepsilon, 94$ & $\varepsilon r$ & متوسط & \\
\hline$r, 1 \wedge$ & וा, & $r, V T$ & $11,0$. & 17 & مرتفع & \\
\hline 7,01 & $r \varepsilon, V_{0}$ & 7,71 & $10, \cdot 7$ & Vr & الكلي & \\
\hline
\end{tabular}

جدول ra

نتائج تحليل التباين الثنائي المصاحب للمتوسطات الحسابية لأداء أفراد الدراسة على اختبار اكتساب المفاهيم العلمية ككل

\begin{tabular}{|c|c|c|c|c|c|c|}
\hline الأثر & الإحصائية & ق ق ق ق ق فيمة ف & متوسط المربعات & الحرية & المربعات & مصدر التباين \\
\hline$\cdot, 0 Y \leq$ & $\cdots, \cdot$ & $T V, \wedge \Lambda$ & YTr, हl & 1 & YTY, \&l & المصاحب(القياس القبلي) \\
\hline - & $\cdot, \cdots$ & $1 \cdot V, 9 v *$ & $\varepsilon \mid v, r \varepsilon$ & 1 & $\varepsilon \mid V, r \varepsilon$ & طريقة التدريس \\
\hline$\cdot$, ONT & $\cdot, \cdots$ & $\leq 0, r Y *$ & 180,17 & r & ro.,rT & التحصيل السابق \\
\hline \multirow[t]{3}{*}{$\cdot, r 01$} & $\cdot, \cdots$ & $1 \cdot, \wedge V^{*}$ & $\varepsilon r, \cdot r$ & r & $\Lambda \varepsilon, .0$ & طريقة التدريس×التحصيل السابق \\
\hline & & & $r, \wedge V$ & 70 & rol, ro & الخطأ \\
\hline & & & & VI & $r \cdot v r, 0 \ldots$ & المجموع المعدل \\
\hline
\end{tabular}

البعدية على الاختبار ككل وفقا لمتغير طريقـة التدريس (نهوذج فراير ، أو الاعتيادية)، و كذلك الكارية لمعر فة لصالح من تلك الفروق؛ استخدم اختبار

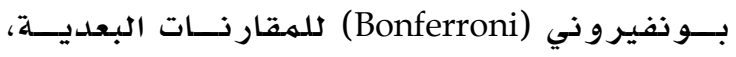

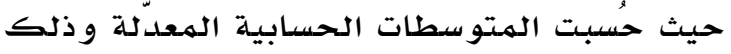

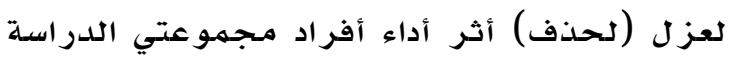

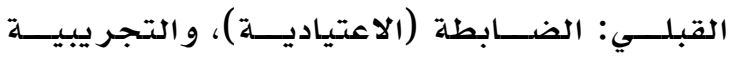

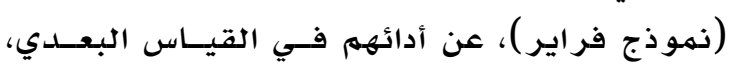

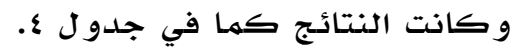

تشير النتائج المبينـة في جدول ع وجود فرق دال

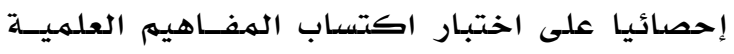

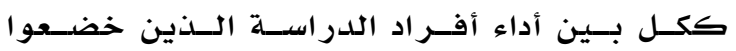
للتدريس بطريقة نهوذج فرايـر ، مقارنــة بـأداء

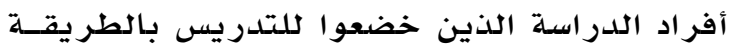

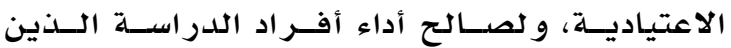

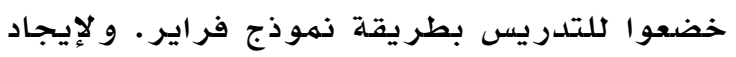

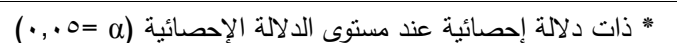

وبالنظر إلى نتائج تحليل التباين جدول r يتبين ما يلي:

أن قيمــة الدلالــة الإحصــائية لهتغيسـر طريقــة

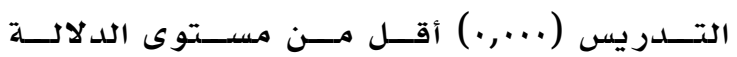

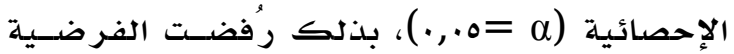

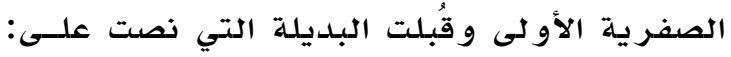

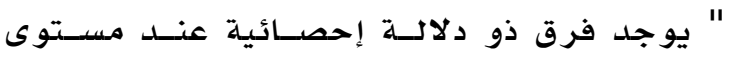

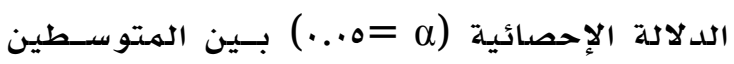

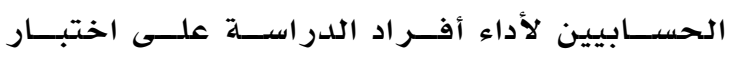

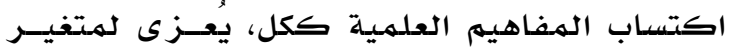
طريقة التدريس (نموذج فراير، أو الاعتيادية)"؛

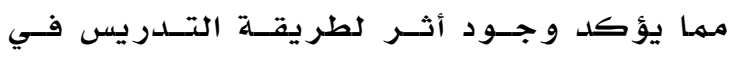

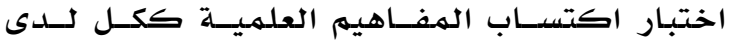
طلاب الصف السـابع الأسـاسـي فـي مـادة العلــوم. و لتحديـد قيمسـة الفـرق -الـدال إحصــائيا- بـين

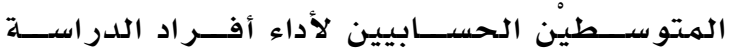




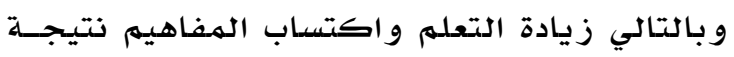

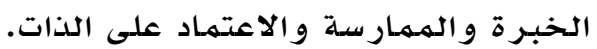
و تتفقق هذه النتيجـة فيما يتعلق بمواد العلوم مــع

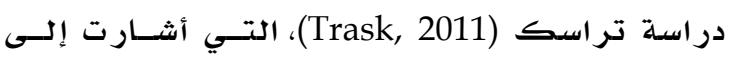
زيادة تحصـيل طـلاب الصـف السـابع للمفـاهيم العلمية الواردة في وحدة الخلايا في مـادة العلوم

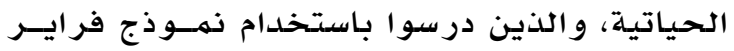
مقارنة مـع السـذين درسـوا بالطريقـة الاعتيـاديـة،

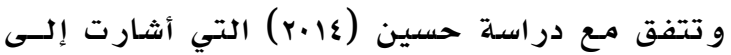
فعالية نموذج فراير في تصحيح الأخطاء الشائعة في المفاهيم الكيميائية لدى طالبات الصف الثير الثاني الهتوسط، كما تتفق هذه النتيجــة مــع دراســات أخرى في مجالات غير العلوم مسـن حيسث فعاليسة

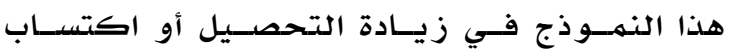
Monroe, Pendergrass, 1997) المفاهيه كدر اسـات

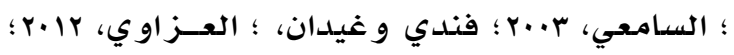
ح :Nahampun \& Sibarani, 2014

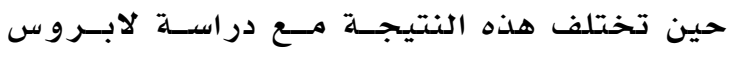
(Labrosse, 2007)

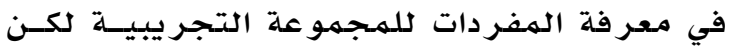

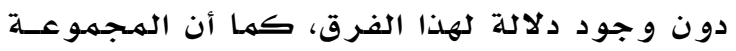
الضابطة لديها فهم للمفاهيهم الكيميائية أعلى من

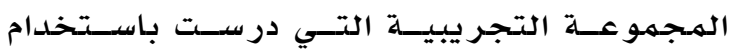

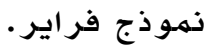

أن قيمة الدلادـة الإحصسائية لهتغيسر التحصـيل السابق (..., إن.) أقل من مستوى الدلالة الإحصدائية

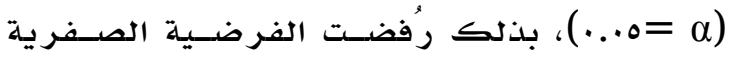

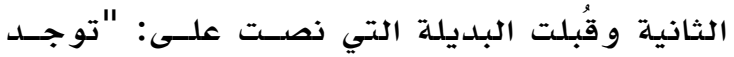
فروق ذات دلالة إحصائية عنــد مســتوى الدلادئة

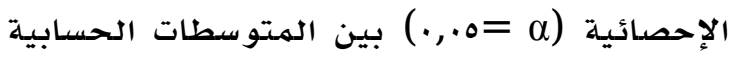

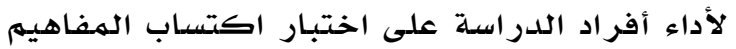

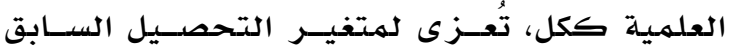

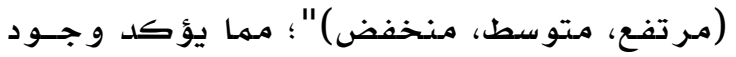

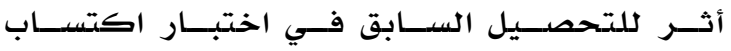

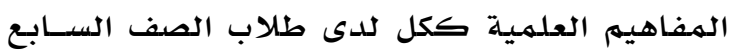
الأسـاسي في مادة العلوم. ولتحديد قيمـة الفـروق

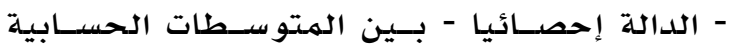

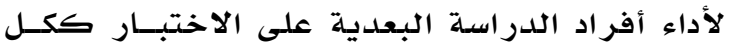

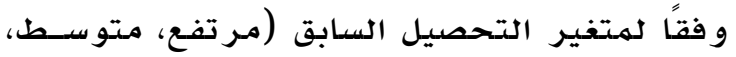

حجـهم أثـر طريقــة التــدريس (نهــوذج فرايـر ،

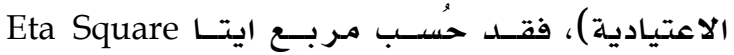

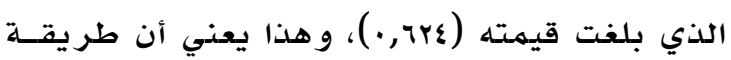

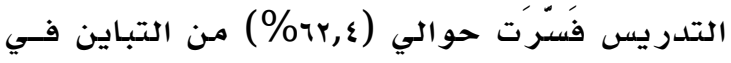

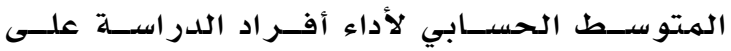
اختبار اكتساب المفاهيهم العلميلة ككل.

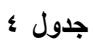

اختبار بونفيروني (Bonferroni) للمقارنات البعدية بين المتوسطات

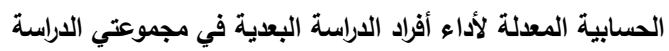

\begin{tabular}{|c|c|c|c|}
\hline \multicolumn{4}{|c|}{ (الضابطة، والتجريبية) } \\
\hline قالمتوسطة الفرق بين الحسابيين & الخطأ & المتوسط & طريقة التدريس \\
\hline \multirow{2}{*}{$0,1 \leqslant \%$} & $\cdot, \varepsilon$. & Tा, $\leqslant \uparrow$ & الاعتيادية \\
\hline & דו & $r v, 1$. & نموذج فراير \\
\hline
\end{tabular}

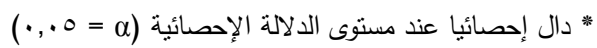

و يمكن تفسير هذه النتيجة في ضوء المزايا التي

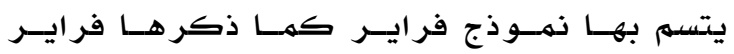
و المشار إليها في كنبيرج (Kinberg, 2007)، بأنه نمـوذج قائم على النظرية البنائية، ويتطلـبـ مسن الطالب تنشيط معرفته السابقة لإكمال المـخطط

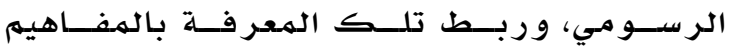

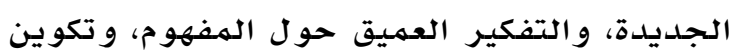

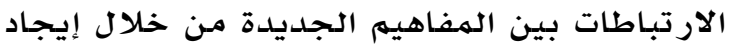

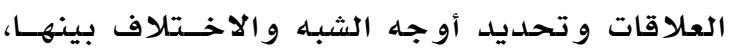
إضـافة إلى أن هذا النـموذج هو تمثيل مـرئي يدمـج

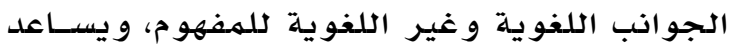

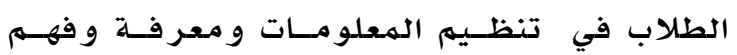
الهفردات غير الشائعة، وكل هذه الهزئ ايـا تـؤدي إلى تعلهم ذي معنى ترتبط فيه المعر فة الجديـدة

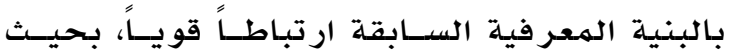

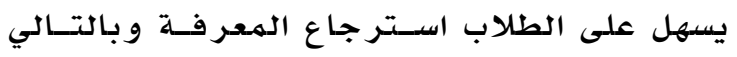
زيادة تحصيلهم و اكتسابهم للمفاهيهم. كما قد تفسر هذه النتيجة في أن طريقة عرض المفاهيم في هـذذا النهــوذج ســاعدت علــى زيـادة النشاط الذاتي لدى الطلاب من خــلال النشـاطات التي تجري داخل الصف، وهذا بدوره ربهما سـاهم في اعتماد الطلاب على أنفسههم في التمييـز بــين

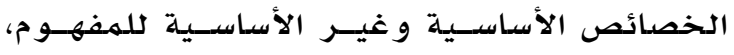

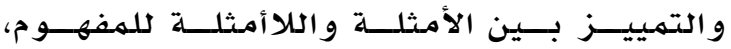


التحصيل المتوسط أو المهنخفض، وبالتالي لديهم قدرة أكبر علـى معرفـة الخصـائص الأسـاسـيـة للهفهوم و تمييزها عن الخصـائص غير الأســـيـة،

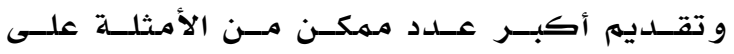
المفهوم و تمييزها عن الللأمثلة، مقارنـة بـالطلاب ذوي التحصيل المتوسط أو المنخفض. ان قيمهة الدلاكلة الإحصائيـة للتفاعل الثنــائي بـين متغيري: طريقـة التـلدريس و التحصسيل الســابق

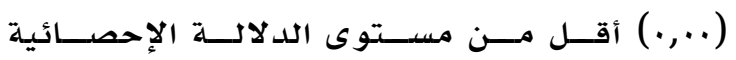
( الثالثة وقبلت البـليلة التي نصت علـى: "ل توجــ فروق ذات دلالة إحصائية عنــد مسـتوى الدلاكلة

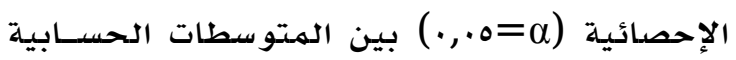
لأداء أفر اد الدراسة على اختبـار اكتسـاب الهفاهيم

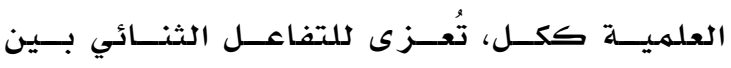
متغيري: طريقة التدريس و التحصسـيل الســابق"؛ مـمـا يؤكسد وجـود أثـر كلتفاعـل الثنـائي بـين متغيري: طريقة التدريس والتحصيل السـابق فـي اختبار اكتســاب الهفـاهيم العلميــة ككـل لـدى طلاب الصف السـابع الأساسـي فـي مــادة العلــوم. و لهعر فة لصالح من تلـك الفـروق؛ تـهم تهثيـل

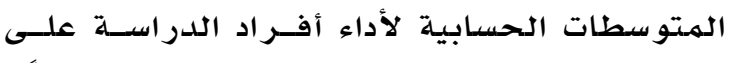
اختبـار اكتسـاب المفـاهيم العلميـة ككـل، وفقـا للتفاعل الثنـائي بين متغيري: طريقـة التـدريس و التحصيل السـابق "، و الشكل م يبين ذلك.

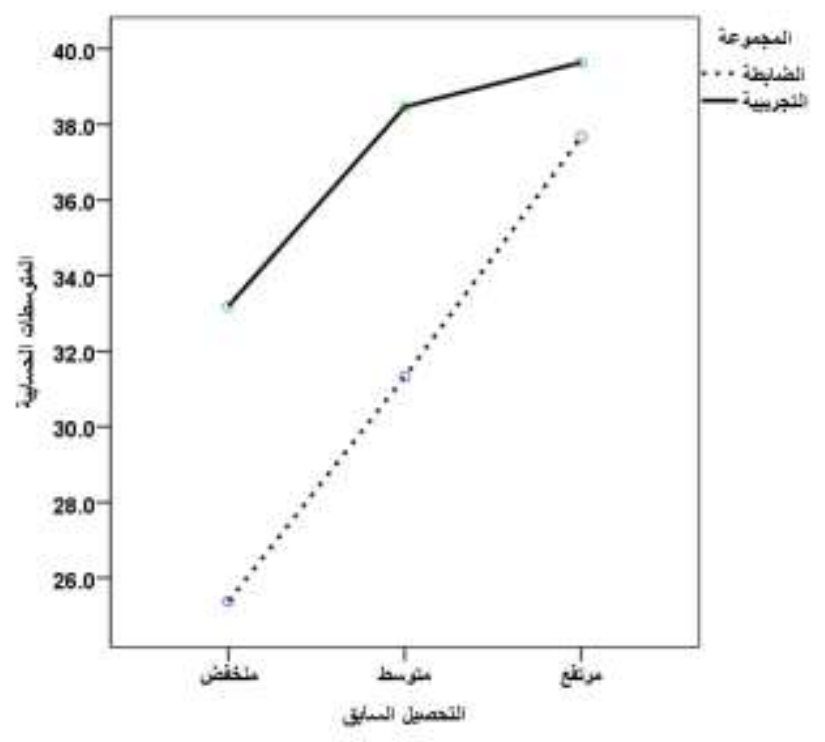

شكل r: التمثيل البياني للمتوسطات الحسابية لأداء أفراد الاراسة على اختبار اكتساب المفاهيم العلمية ككل
منخفض)، و كذلك لمعرفة لصسالح مـن تلـك

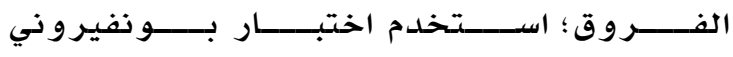

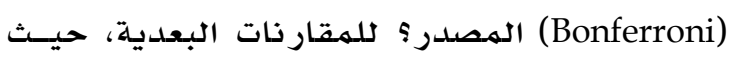

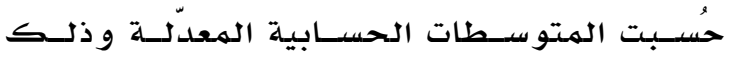
لعزل (لحذف) أثر أداء أفر اد مسجهو عتي الدراسلة

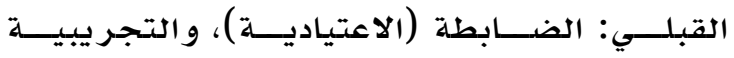

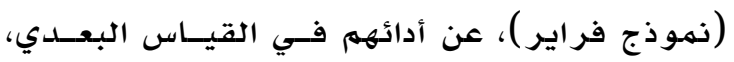
و كانت النتائج كما في جدول ل ه.

جدول

اختبار بونفيروني (Bonferroni) المصدر؟ للمقارنات البعدية بين

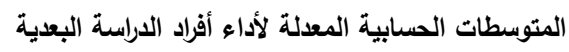

\begin{tabular}{|c|c|c|c|c|}
\hline \multicolumn{2}{|c|}{ قالحسابيين الفرق بين المتوسطين } & \multirow{2}{*}{ الخطنأ } & \multirow{2}{*}{ المستوسط المعدل } & \multirow{2}{*}{ التحصيل } \\
\hline مرتفع & متوسط & & & \\
\hline $9, \Gamma \wedge *$ & $0,7 Y *$ & $\cdot, 70$ & $r q, Y \wedge$ & منخفض \\
\hline \multirow[t]{2}{*}{$\Gamma, \vee\urcorner *$} & & $\cdot, r$. & $r \varepsilon, q$. & متوسط \\
\hline & & $\cdot, 09$ & rᄉ, \૫ & مرتفع \\
\hline
\end{tabular}

تشير النتائج الهبينـة في جدول 0 وجسود فـروق دالة إحصــائيا علـى اختبــار اكتســاب المفــاهيم العلميــة ككـل بـين أداء أفـراد الدراســة الـذين الذين تحصسـيلهم الســابق (مسنخفض، متوســ)، و أداء أفراد الدراسـة الذين تحصيلهم السـابق (مـرتفـع)، و لصسـالح أداء أفـر اد الدراســة الـذين تحصسيلهم

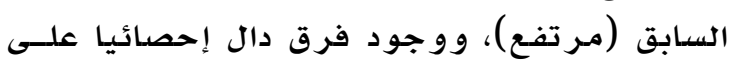
اختبار اكتسـاب الهفاهيه العلميـة ككل بـين أداء

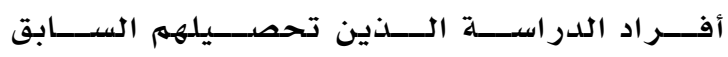

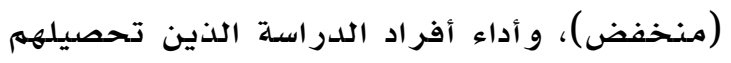

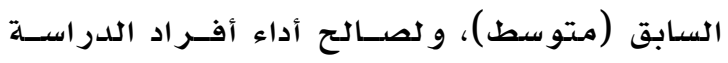

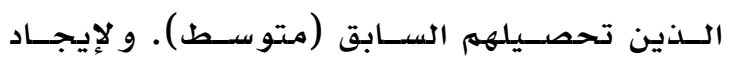

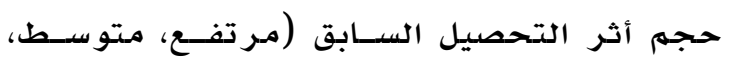

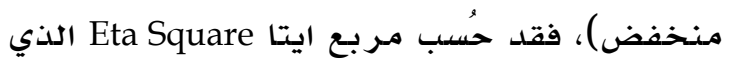

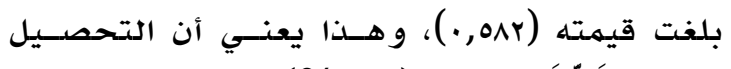

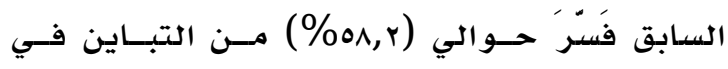

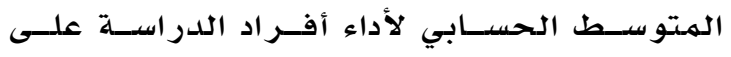
اختبار اكتسساب المفاهيهم العلميية ككل. ويهكن تفسير هذه النتيـجة فـي ضـوء مــا أثـار إليه فراير وروفاقه (Frayer et al, 1969) من أهميـة

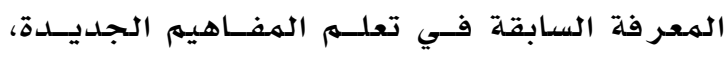
حيث إن الطـلاب ذوي التحصديل العـالي لــديهم مسخزون معرفي ســابق أكبـر مسـن الطـلاب ذوي 


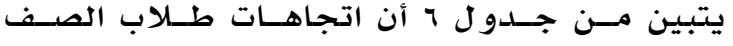

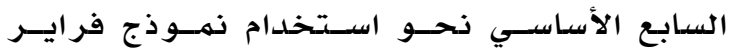

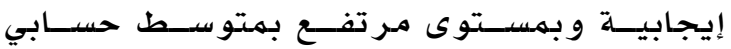

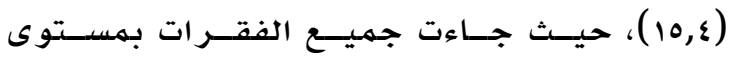

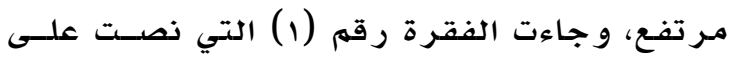
"يساعدني نموذج فراير على المشاركة أفة الإيجابية

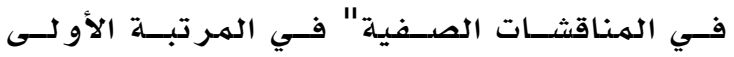

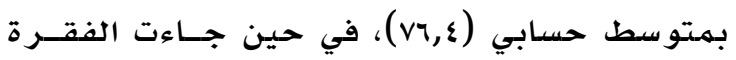
رقم (ع) التي نصت على " يسـاهم نهــوذج فر ايسر في تعلهم العلوم في تغييــر روتـين العمـل داخــل

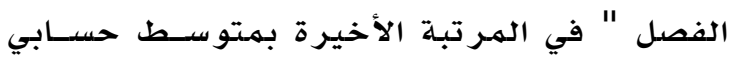
.$(\uparrow \wedge, r)$

ويمكن تفسير الاتجاهات الايجابية للطلبــة نحسو

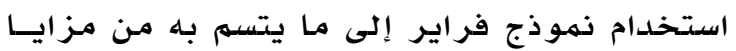
إيجابية عديدة، كالدور النشط للطالب، وتعـاون

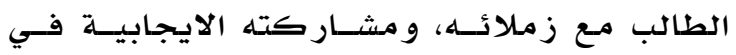

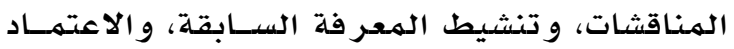

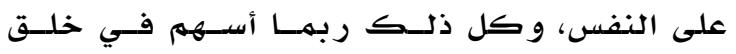

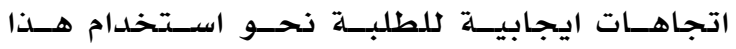
النهوذذج في التدريس. وتتفق هــذه النتيجسة مــع

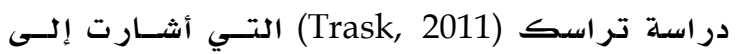
تفضيل طلبـة الصف السـابع لنهــوذج فرايـر لأنسه يزيد من تعلمهم لمحتوى الوحدة و فهمهم لدلادلة

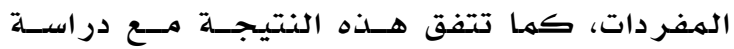

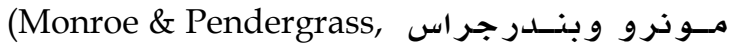

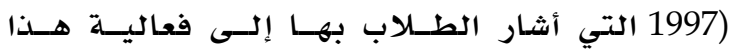
النهموذج و استمتاعهم بـه.
تشير النتائج الهبيـنة مـن الثـكل م تفـوق أفـراد

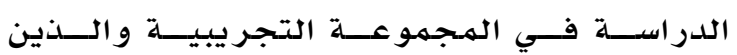

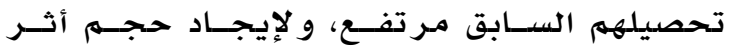

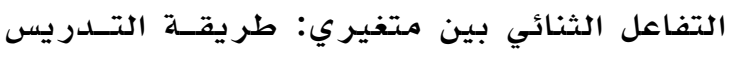

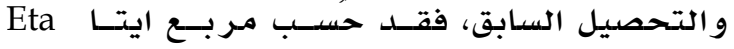
Square التفاعل الثنائي بين متغيري: طريقـة التـدريس

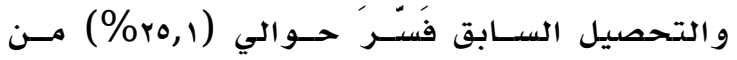
التباين في المتوسط الحسابي لأداء أفراد الدراسلة الست الدي على اختبار اكتساب المفاهيهم العلمية ككل. كما يلاحظ مـن الشكل r أن اكتسـاب المفـاهيم

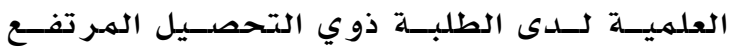
و الذين درسوا باستخدام نموذج فراير أفضل مسن

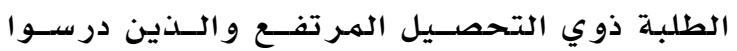
بالطريقة الاعتياديـة، و لكـن بفــارق قليـل بـين متوسطيهمـا. أما مجهموعتي الطلبـة ذوي التحصيل المسنـخفض (اسـذين درسـوا بـالاعتياديـة، و الـذينين

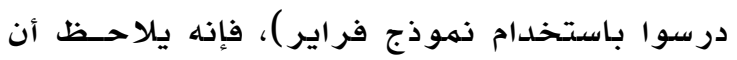
اكتسـاب المفـاهيم لـدى الطلبــة ذوي التحصـيل المنـخفض الذين درسوا باستخدام نهـوذج فرايـر كان أفضـل بكثيـر مــن الطلبــة ذوي التحصـيل المنـخفض و الـذين درســوا بالاعتياديـة، و بفــارق كبير بين متوسطيهما، وهذا يدلل على ما أثـار

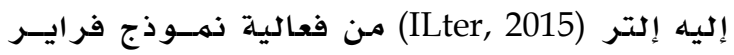

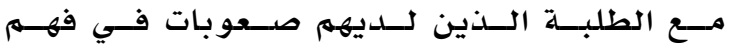

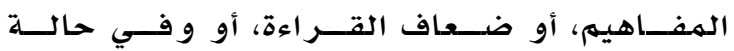
الهفاهيم الهـجر دة و الهعقدة. ثانياً: نتائج السؤال الثاني الذي نص علـى: "مــا اتجاهات طــلاب الصـف السـابع الأساسـي نحسو "استخدام نموذج فراير في تعلمهم العلوم؟

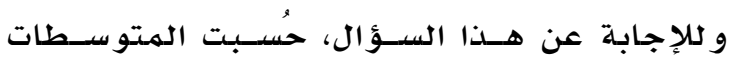

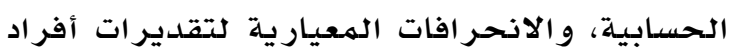

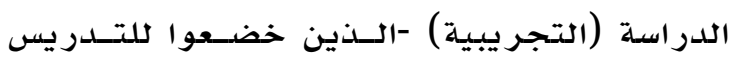
بطريقة نموذذج فراير - على كل فقرة من فقر ات

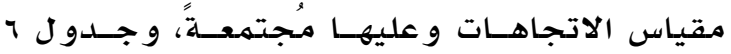
يبين ذلك. 
جدول 1

المتوسطات الحسابية، والانحرافات المعيارية لتقيرات أفراد الدراسة (التجريبية) -الذين درسوا بطريقة نموذج فراير - على كل فقرة من فقرات مقياس

الاتجاهات وعليها مجتمعة

\begin{tabular}{|c|c|c|c|c|c|c|}
\hline 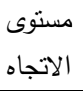 & 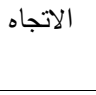 & الرتبة & المعياري & 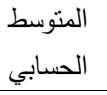 & 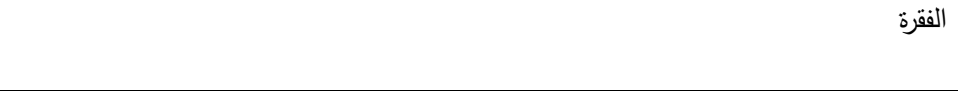 & رقمرة \\
\hline 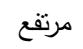 & ايجابي & 1 & $\cdot, \varepsilon r$ & $\varepsilon, \vee \uparrow$ & ني نموذج فراير على المشاركة الإيجابية في المناقشات الصفية. & 1 \\
\hline 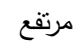 & ايجابي & r & $\cdot, \sum \wedge$ & $\varepsilon, 70$ & يساعدني نموذج فراير في تبسيط مفاهيم العلوم مقارنة بالطريقة التقليدية. & 17 \\
\hline 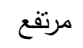 & ايجابي & r & $\cdot, 00$ & $\varepsilon, O \mathrm{~V}$ & أثشعر في الاستمتاع عندما أنعلم باستخدام نموذج فراير . & ir \\
\hline 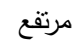 & ايجابي & $\varepsilon$ & $\cdot, 71$ & $\varepsilon, 0 \leqslant$ & استخدام نموذج فراير في تعلم العلوم يزيد من تحصلي الدراسي. & $r$ \\
\hline 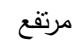 & ايجابي & $\circ$ & $\cdot, 7)$ & $\varepsilon, 0 \leqslant$ & يتحسن فهمي للعلوم عندما أتعلم باستخدام نموذج فراير . & $\wedge$ \\
\hline 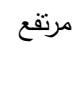 & ايجابي & 7 & $\cdot, 7$ & $\varepsilon, 01$ & للمفهوم. ليسني استخدام نموذج فراير على التمييز بين الخصائص الأساسية والخصائص غير الأساسية & $1 \varepsilon$ \\
\hline 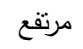 & ايجابي & $\checkmark$ & $\cdot, 07$ & $\varepsilon, 01$ & التعليم التقليدي أكثر تشويقاً من التعليم باستخدام نموذج فراير . & rr \\
\hline 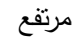 & ايجابي & $\wedge$ & $\cdot, 70$ & $\varepsilon, \leqslant 7$ & تزداد دافعيتي لتعلم العلوم عندما يستخدم المعلم نموذج فراير في التدريس. & r. \\
\hline 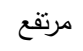 & ايجابي & 9 & $\cdot, 79$ & $\varepsilon, \varepsilon 1$ & يساعدني نموذج فراير على التمييز الدقيق بين الدفاهيم المتقاربة. & it \\
\hline 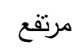 & ايجابي & $1 \cdot$ & $\cdot, \mathrm{V} \leqslant$ & $\varepsilon, \Gamma \cdot$ & تعلمي باستخدام نموذج فراير يجعل المعلومات لدي أكثر ثباتاً مقارنة بالطريقة التقليدية. & 9 \\
\hline 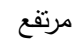 & ايجابي & 11 & $\cdot, 70$ & $\varepsilon, 17$ & أشعر بثقة بالنفس عندما أتعلم باستخدام نموذج فراير . & 7 \\
\hline 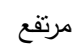 & ايجابي & ir & $\cdot, 7$ & $\varepsilon, 11$ & أشعر أن مفاهيم العلوم تصبح أكثر تعقيداً باستخدام نموذج فراير . & 11 \\
\hline 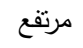 & ايجابي & 1 & $\cdot, \uparrow \wedge$ & $\wedge$ & استخدام نموذج فراير يعيق تعلمي لمفاهيم العلوم. & r \\
\hline 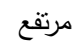 & ايجابي & $1 \varepsilon$ & $\cdot, 00$ & $\varepsilon, \cdot r$ & تتتمى لدي مهارات التقكير العليا عندما أتعلم باستخدام نموذج فراير . & 11 \\
\hline 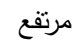 & ايجابي & 10 & $\cdot, 7 \leq$ & ५, १४ & أنشعر بالملل والضجر عندما يدرسنا معلم العلوم باستخدام نموذج فراير. & $\bullet$ \\
\hline 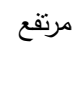 & ايجابي & 10 & $\cdot, 7 \leqslant$ & ५, १४ & تنقهم بيئة التعلم باستخدام نموذج فراير في وجود فصول تفاعلية نشطة لا تتوفر في التعليم & 19 \\
\hline مرتفع & ايجابي & 10 & $\cdot, 7 \leqslant$ & ५,१९ & أرى أن استخدام نموذج فراير يستثمر وقت الحصة بشكل فعال. & rv \\
\hline 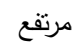 & ايجابي & 11 & $\cdot, \mathrm{OV}$ & r, 90 & يقل اعتمادي على المعلم عندما أتعلم باستخدام نموذج فراير . & 1. \\
\hline مرتفع & ايجابي & 19 & $\cdot, \leqslant 9$ & r,q & أتحمل مسؤولية تعلمي بنفسي ولا أعتمد على الآخرين عندما أتعلم باستخدام نموذج فراير . & 10 \\
\hline 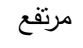 & ايجابي & 1 & $\cdot, \uparrow \cdot$ & r,q & يسهم استخدام نموذج فراير في تقوية علاقتي بمعلمي. & 11 \\
\hline 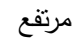 & ايجابي & rl & $\cdot, 77$ & ५,^৭ & أرى أن استخدام نموذج فراير في التدريس مضيعة للوقت. & iv \\
\hline 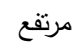 & ايجابي & r) & $\cdot, 74$ & ґ,^৭ & أشعر أن تعلم العلوم باستخدام نموذج فراير بزيد من قدراتي الإبداعية. & r \\
\hline 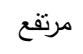 & ايجابي & r & זדו, & r,人 & بساعدني نموذج فراير في تقبل واحترام أفكار زملائي. & $\mathrm{v}$ \\
\hline مرتفع & ايجابي & r & $. .0 \leqslant$ & r,人т & أشعر أن الوقت يمضي سريعاً عند تعلم مفاهيم العلوم باستخدام نموذٍ فراير . & r \\
\hline 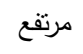 & ايجابي & ro & .00 & $r, \wedge \varepsilon$ & أثشعر أن تعلم مفاهيم العلوم باستخدام نموذج فراير يتطلب مني جهداً يفوق قدراتي. & $r \leq$ \\
\hline 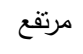 & ايجابي & ז &. .07 & $r, v r$ & أثعر أن استخدام نموذج فراير في تعلم المفاهيم العلمية يقوي شخصيني. & ro \\
\hline 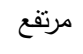 & ايجابي & rv & $\cdot, 0$ r & $\uparrow, \uparrow \uparrow$ & يساهم نموذج فراير في تعلم العلوم في تغيير روتين العمل داخل الفصل. & \\
\hline 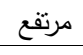 & ايجابي & & $\cdot, r_{1}$ & $\varepsilon, 10$ & مُجتمعةً & الفقر \\
\hline
\end{tabular}

يتبين من جدول V أن قيمة الدلالة الإحصـائية

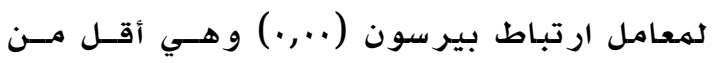

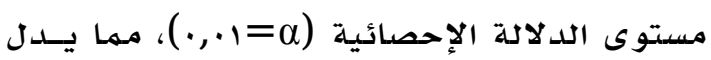
على وجود علاقة ارتبـاط دالسة إحصسائيا بـين اكتساب طلاب الصف السـابع الأساسي للهفاهيم

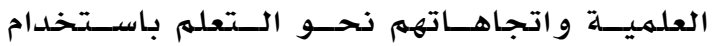
نهوذج فر اير، حيث بلغ معامل الارتباط (به, •). ويمكن تفسير هذه العلاقة القوية، في أن نموذج

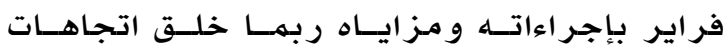
ايجابية لدى الطلاب نحو استخداءمهـ في التدريس،

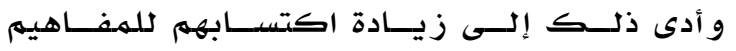

ثانثًا: نتائج السؤال الثالث الذي نص ملى: "هل توجد علاقة ارتباطية بين اكتساب طلاب الصف السابع الأساسي للمفـاهيم العلميـة واتجاهـــاتهم

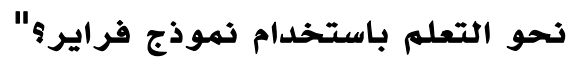
و للإجابة عن هذا السؤال، حُسب معامل ارتبـاط بيرسون بين أداء أفراد الهـموعة التجريبيـة -

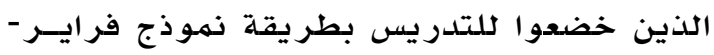
على اختبار اكتســاب المفــاهيم العلميـة ككـل

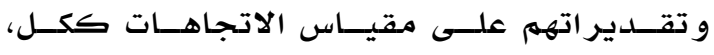
والجدو ل ليبين ذلك. 
ع- إجراء الهزيلد من اللدراسـات باستخدلام نمـوذج

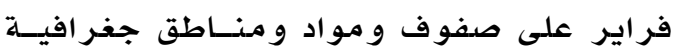

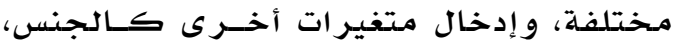

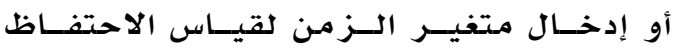

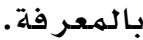

\section{المر اجح}

\section{References}

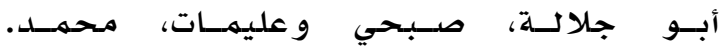

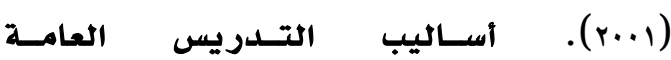

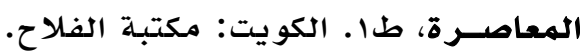

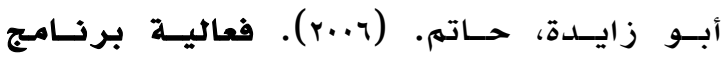

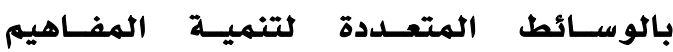
والـوعي الـصحي فـي العلـوم رـلدى طلبـة

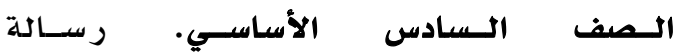
ماجسستير غيـر منسشورة -كلية التربية، الجامعة الإسلاميلة، غزة.

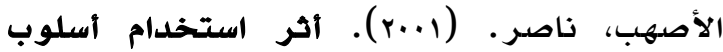
المماثلة في تعديل المفاهيم الخطا للتيار الكهربائي الثابت للىى طلاب الصف الصفاشر الأساسي. رسالة ماجستير غير منشوره، جامعة الير موك، الأردن.

جناد، روعة. (1994). أثر استخدام نموذج جانييه في تعليم المفـاهيم فـي مادة العلوم. رسالة ماجستير غير منشورة. كلية التربية، جامعة دمشق.

الجزار، عبد اللطيف. (r..r). فعالية استخدام التعليهم بمساعدة الكمبيوتر متعدد الوسائط فى اكتساب بعض مستويات تعلم المفاهيم

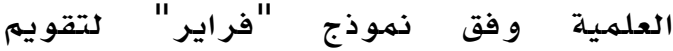
المفاهيه. مجلة التربية لبحوث التربوية والنفسية والاجتماعية. كلية التربية، جامعة الاهية

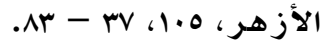

الحدابي، داود، والدعيسى، صفية. (1990).

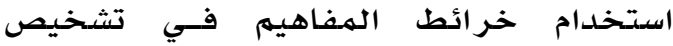
المفاهيم البيولوجية لدى طلبـة الصف الثاني الثانوي، مجلة كليـة التربية، جامعة صنعاء،
العلمية، وربما كذلك يكون العكس، في أن هــذا

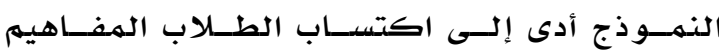
العلميــة، وهنــا بـدور جعـل الطــلاب يشـعرون بالنجاح، فأدى ذلك إلى اتجاهات إيجابية للطلاب نحو استخدام هذا النهموذج. جدول

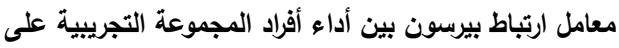

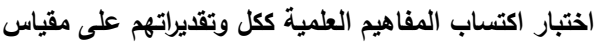

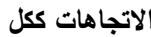

\begin{tabular}{|c|c|c|}
\hline \multicolumn{3}{|c|}{ التقديرات على مقياس الاتجاهات ككل } \\
\hline ***, & معامل ارتباط بيرسون & الأداء على اختبار \\
\hline$\cdot, \cdots$ & الدلالة الاحصائية & اكتساب المفاهيم \\
\hline rV & 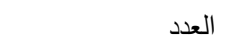 & العلمية ككل \\
\hline
\end{tabular}

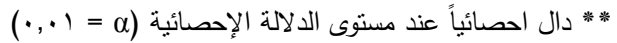
التوصيات استناداً إلى نتائج الدراسـة، يوصى بالآتي: 1- أظهر ت النتائج أن استخحام نموذج فرايـر لـهـ أثر إيجابي في كل من: اكتســاب المفـاهيم

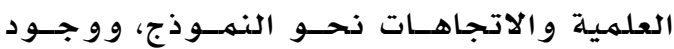

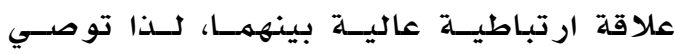

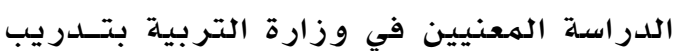

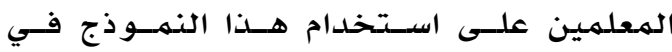
تدريس المفاهيه، كما توصي لجـان تخطـيط الميط

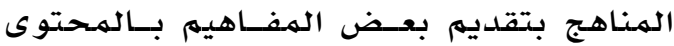
الدـر اسي باستخدام نهوذذج فر اير • Y- أظهرت النتائج أن التحصيل السـابق الهـرتفـع يزيد عن اكتسـاب الطلبـة للمفــاهيه العلميـة، لذا توصي الدراسـة المعلمين بمراجعة الطلبـة

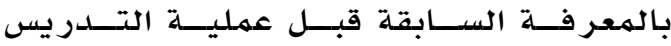
باستخدام نموذج فر اير •

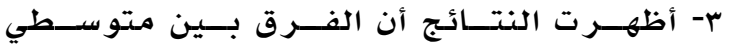

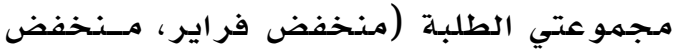

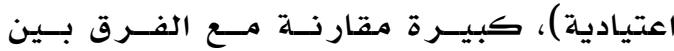

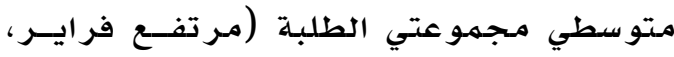

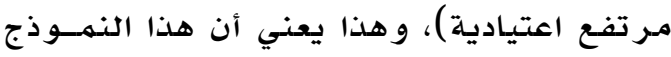
أكثر فاعلية مـع الطلبة منخفضي التحصديل،

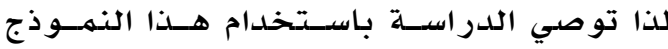

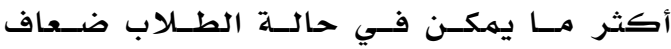
التحصيل أو الذين لديهم صعوبات في التعلهم. 


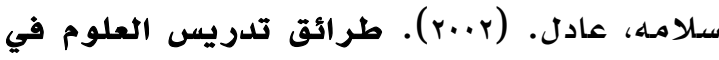

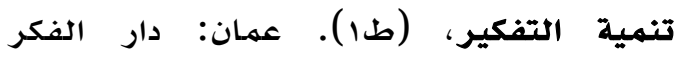
كلنشر.

عبد الباري، ماهر شعبان. (11) (1). استراتيجيات

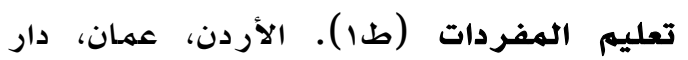

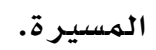

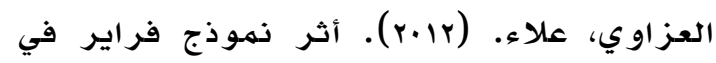

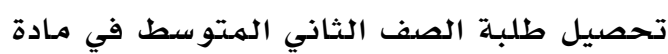

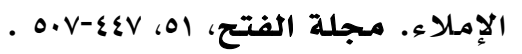

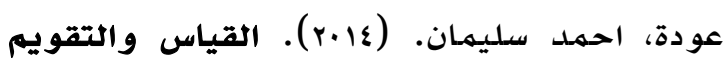
في العملية التدريسية. إربد: دار الأمل للنشر

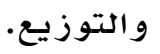

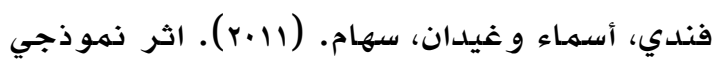

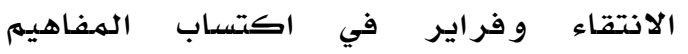
النحوية لدى طالبات الصف الاول المتوسط. مجلة الفتح، V乏، عץ-00.

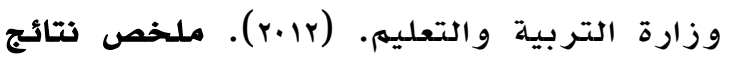

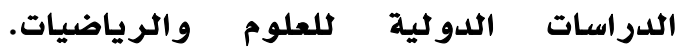
المركز الوطني لتنمية القوى البشرية،

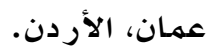

Costa, A, Garmston, R. (2001). Cognitive Coaching :A Founda Tion for Renaissanee schools. Nor Wood, M A , Christopher Gordan PhDs.

Dunn, D. \& Price, G. (1987). Learning style inventory. Lawrenca: Price system, K.S.

Fishman, B., Marx, R., Best, S., \& Tal, R. (2003). Linking teacher and student learning to improve professional development in systemic reform. Teaching and Teacher Education, 19(6), 643-658.

Frayer, L. E., Fredrick, W. C., \& Klausmeier, H. J. (1969). A Schema for testing the level of concept mastery, Working paper No. 16, Madison, Wisconsin: Wisconsin research and development center for cognitive learning, University of Wisconsin.

ILter, I. (2015). The investigation of the effects of Frayer model on vocabulary knowledge in social studies. Elementary Education Online, 14(3) , 1106-1129.

Karjala, L. (2010). Math vocabulary instruction in an inclusive classroom 1 direct instruction and

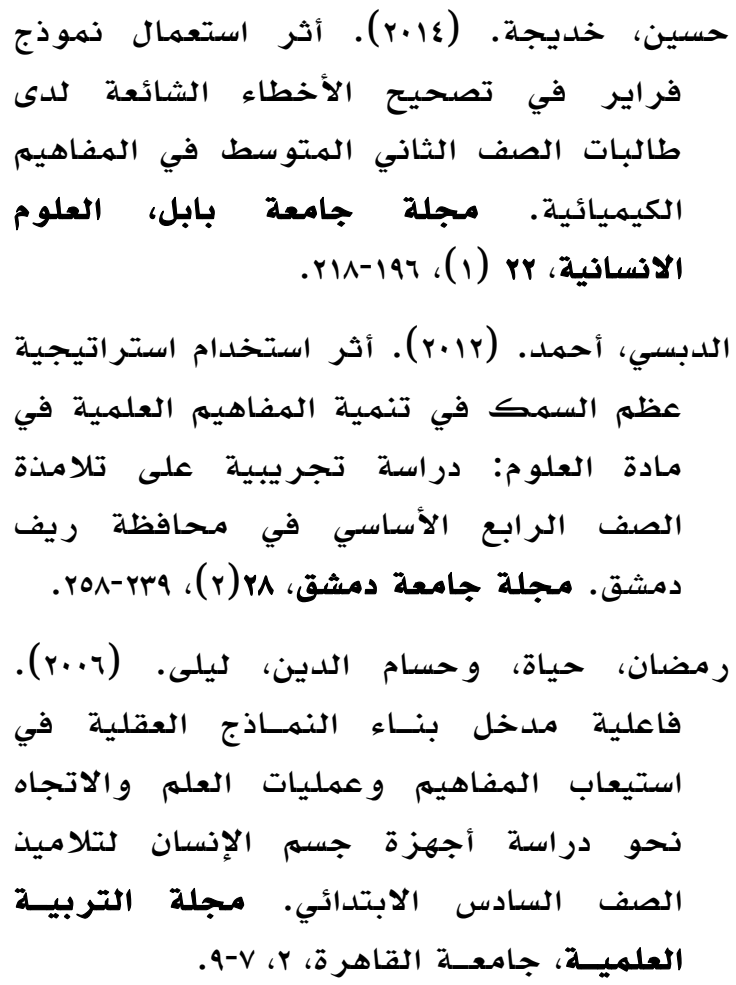


the Frayer model: Effects on mathematics achievement in an inclusive classroom. (Unpublished master thesis). South West State University Marshall Minnesota

Kinberg, M. (2007). Teaching reading in the content areas for elementary teacher. Hunting Beach, shell education.

Labrosse, p. (2007). Analysis of the effect of specific vocabulary instruction on high school chemistry students' knowledge and understanding. Unpublished doctoral dissertation, University of Massachusetts lowell. Retrieved in 28 April 2015 from the website:

www.adsabs.harvard.edu/abs/2007PhDT $.40 \mathrm{~L}$

Macceca, S. (2007). Reading strategies for social studies. Washington: Shell education.

Monroe, E.E., \& Pendergrass, M.R. (1997). Effects of mathematical vocabulary instruction on fourth grade students. Reading improvement, 34(3), 120- 132.

Nahampun, E.E., \& Sibarani, B. (2014). The effect of using Frayer model on students' vocabulary mastery. General Jounral of Applied Linguistics of FBS Unimed, 3(1), 1-8.

National Research Council. (2000). Inquiry and the national science education standards: a guide for teaching and learning. National academy press, Washington.

Teacher Resource Guid. (2006). Florida center for reading research. Retrieved in 8 May 2015 from the website: http://www.fcrr.org/curriculum/PDF/G 2-3/2-3TRG_2.pdf. TNR Font

Trask, C.P. (2011). Raising achievement of special education students through vocabulary instruction. Lagrange University, Georgia. 